\title{
PUBLIC TRANSIT BUS PROCUREMENT: \\ THE ROLE OF ENERGY PRICES, REGULATION AND FEDERAL SUBSIDIES
}

\author{
Shanjun Li \\ Matthew E. Kahn \\ Jerry Nickelsburg \\ Working Paper 19964 \\ http://www.nber.org/papers/w19964 \\ NATIONAL BUREAU OF ECONOMIC RESEARCH \\ 1050 Massachusetts Avenue \\ Cambridge, MA 02138 \\ March 2014
}

We thank Ed Glaeser, David Levinson, Ben Leard, Ian Savage, Duncan Watry and seminar participants at Arizona State University and the National University of Singapore, University of Chicago, Texas A\&M and the University of Wisconsin at Madison for useful comments. The views expressed herein are those of the authors and do not necessarily reflect the views of the National Bureau of Economic Research.

NBER working papers are circulated for discussion and comment purposes. They have not been peerreviewed or been subject to the review by the NBER Board of Directors that accompanies official NBER publications.

(C) 2014 by Shanjun Li, Matthew E. Kahn, and Jerry Nickelsburg. All rights reserved. Short sections of text, not to exceed two paragraphs, may be quoted without explicit permission provided that full credit, including $\odot$ notice, is given to the source. 
Public Transit Bus Procurement: The Role of Energy Prices, Regulation and Federal Subsidies Shanjun Li, Matthew E. Kahn, and Jerry Nickelsburg

NBER Working Paper No. 19964

March 2014

JEL No. R41,R48

\begin{abstract}
$\underline{\text { ABSTRACT }}$
The U.S. public transit system represents a multi-billion dollar industry that provides essential transit services to millions of urban residents. We study the market for new transit buses that features a set of non-profit transit agencies purchasing buses primarily from a few domestic bus makers. Unlike private vehicles, the fuel economy of public buses is irresponsive to fuel price changes. To understand this finding, we build a model of bus fleet management decisions of local transit agencies that yields testable hypotheses. Our empirical analysis of bus fleet turnover and capital investment suggests that transit agencies: (1) do not respond to energy prices in either their scrappage or purchase decisions; (2) respond to environmental regulations by scrapping diesel buses earlier and switch to natural gas buses; (3) prefer purchasing buses from manufacturers whose assembly plants are located in the same state; (4) exhibit significant brand loyalty or lock-in effects; (5) favor domestically produced buses when they have access to more federal funding.
\end{abstract}

Shanjun Li

Cornell University

405 Warren Hall

Ithaca, NY 14853

s12448@cornell.edu
Jerry Nickelsburg University of California, Los Angeles

Anderson School of Management

Los Angeles, CA 90095

jerry.nickelsburg@anderson.ucla.edu

Matthew E. Kahn

UCLA Institute of the Environment

Department of Economics

Department of Public Policy

Anderson School of Management

UCLA Law School, Box 951496

Los Angeles, CA 90095-1496

and NBER

mkahn@ioe.ucla.edu 


\section{Introduction}

In 2011, public transit riders in the United States traveled 56 billion passenger miles. $38 \%$ of these miles were covered by public buses. Public transit agencies spend about $\$ 2.5$ billion on new buses and $\$ 3.5$ billion to maintain the existing stock. ${ }^{2}$ In 1991 , the aggregate capital and operating expenditure on public transit equaled $\$ 36.3$ billion (in 2011 dollars) and this grew to $\$ 55$ billion by 2011. There were over 60,000 public transit buses operating in 2011 . Chicago had 1,786 buses while Las Vegas had 420 buses.

Public transit agencies' bus purchase decisions represent a distinctive market transaction featuring a non-profit (the public transit agency), who has a local monopoly providing transit services, purchasing expensive durable capital from for-profit firms who compete in a differentiated goods market. Such transit agencies often use "other people's money" (federal transfers) to purchase their capital. We study the revealed preference of these agencies and compare and contrast their choices with those exhibited by private vehicle buyers (McFadden 1976).

We know of no recent economics research investigating bus procurement and fleet management. This research gap is notable because public buses play a central role in providing basic transportation services for a large share of the urban poor and constitute an important element of urban quality of life. Public buses also represent a viable substitute for private vehicle driving. If urban travelers substitute from using cars to riding the bus there could be significant impacts on reducing three key urban externalities: air pollution, greenhouse gas emissions from automobiles, and road congestion (Parry and Small 2005, 2009).

This paper presents new evidence on the demand and supply of U.S. public transit buses. A surprising result that emerges from our analysis is that the fleet fuel economy of buses does not appear to be responsive to fuel prices. Unlike private vehicle buyers, public transit agencies face a set of incentives and constraints that reduce their demand for more fuel-efficient international products. In the case of the private vehicle market, consumers respond to gas prices in choosing whether to scrap their existing vehicle and in choosing their new utility maximizing vehicle (Li, Timmins and von Heafen 2009). During times when gas prices are high, consumers seek out imports such as the Toyota Prius and for-profit sellers direct their product mix and

\footnotetext{
${ }^{2}$ Source: 2013 Public Transportation Fact Book.
} 
innovation efforts to supply such vehicles. Such induced innovation shifts the attributes bundled into differentiated products at any point in time (Newell, Jaffe and Stavins 1999, Knittel 2012). The automobile market features private firms selling to private individuals. Auto-makers all over the world compete for U.S. consumers. This competition leads to a wide range of differentiated products in a rich attribute space for consumers.

In the case of public buses, a large number of different buses are produced around the world and highly fuel-efficient buses are produced in China, Japan and South Korea. However, the U.S. public bus fleet is predominantly produced by domestic sellers who focus on the U.S. market and who are small in scale relative to major international bus makers. As public entities, U.S. transit agencies must comply with the U.S. rules and regulations that we describe below. The domestic bus buyers reveal a very low demand for purchasing foreign buses and their fleet turnover decisions are driven by a variety of factors other than energy prices. These in turn lead to the zero correlation between fuel prices and the public transit fleet's overall fuel economy.

We build a model of bus procurement and bus scrappage decisions for local transit agencies that yields testable hypotheses. A public transit agency has a very different optimization problem than private individuals or businesses as it trades off the costs of operating expenses such as vehicle maintenance; capital expenses; complying with Federal Clean Air Act regulation; and pleasing various constituents such as labor unions and funding agencies. Transit agencies are expected to guarantee a certain level of transit service to the cities they serve. In providing this service, they recognize that past investments in mechanic human capital, spare parts for specific buses and characteristics of their repair facilities all create an asset and human capital specificity that encourages them to concentrate their bus purchases on brands they have previously bought (Williamson 1988). In addition, public transit systems face mandatory "Buy America" requirements from the Federal government when availing themselves of Federal subsidies. By affecting the relative "effective" price of internationally traded goods, the Buy American policy causes distortions in the allocation of resources in much the same way that a tariff does (Lowinger 1976). The public transit systems located in cities whose county is not in compliance with the Clean Air Act will face mandates to purchase specific types of buses such as buses that run on compressed natural gas $(\mathrm{CNG})$ or hybrid buses.

We estimate a series of reduced form models of fleet inventory dynamics and new bus demand to document the role these various factors play. We examine how different agencies 
manage their bus inventory as they face various constraints such as the Buy America requirement and environmental regulations and recognize that maintenance costs are increasing in a vehicle's age and cumulative mileage. Our results show: (1) transit agencies in non-attainment counties (counties designated by the EPA as having sub-standard air quality) for Ozone and PM2.5 tend to scrap their diesel buses earlier than others and more likely to buy natural gas buses; (2) bus scrappage and purchase decisions do not respond to fuel prices; (3) transit agencies tend to buy buses of the same make and fuel type as what they already have, which we characterize as brand loyalty or lock-in effects; (4) transit agencies prefer purchasing buses from manufacturers whose plants are located in the same state; (5) the inflow of federal funding expedites the scrappage of old buses and increases purchases of domestically produced buses.

In Section 2, we present a detailed analysis of the bus fleet's fuel economy dynamics as a function of energy prices and we contrast these estimates with the private vehicle stock. This set of results yields a stark contrast between the investment choices pertaining to the public capital stock (buses) versus the private transportation capital stock (cars). Section 3 describes the bus procurement environment. Section 4 provides a model of transit authority decisions to help motivate our empirical model. In Section 5, we first discuss our data and present our empirical tests regarding bus procurement practices by transit agencies. We then discuss the implications of these findings and conclude.

\section{Fleet Fuel Economy of U.S. Public Transit Bus is Energy Price Inelastic}

Ongoing research in environmental and energy economics has studied how the private vehicle fleet's composition and utilization responds to gas price dynamics. These studies have generally concluded that both new vehicle purchases and used vehicle scrappage respond to gasoline prices (Li, Timmins, von Haefen 2009, Klier and Linn 2012, Knittel 2012, and Jacobsen and van Benthem 2013). At the intensive margin, households reduce driving where gasoline price rises (Small and van Dender 2007, Gillingham 2013).

In this section, we examine the fuel economy trends for public buses. We focus on the comparison with cars instead of the private fleet of heavy-duty trucks such as Fed Ex or greyhound buses due to data limitations. The demand for Fed Ex and Greyhound reflects the 
need for cargo shipment and long-distance travel while transit buses and cars are used mostly for within-city passenger travel. ${ }^{3}$

Figure 1 shows the correlation of bus fleet fuel economy and gasoline price and contrasts it with private passenger vehicles from 1997 to 2011. The top panel of Figure 1 plots the average fleet fuel economy of public buses and gasoline prices. The fleet fuel economy of buses is constructed based on data from the National Transit Database (NTD) maintained by Federal Transit Administration (FTA) and the data will be discussed in detail in Section 4.1. The bottom panel shows the average fleet fuel economy of passenger vehicles from National Transportation Statistics from the Department of Transportation. Both series of fleet fuel economy exhibit an increasing trend over time and they appear to have a positive correlation with gasoline prices. Examining the growth rate over time, the average mpg of buses increased from 3.35 to 3.54 during the period, with an annual growth rate of $0.50 \%$. The average MPG of passenger vehicles increased from 21.5 to 23.5 during the period, with an annual growth rate of $0.74 \%{ }^{4}$

Unlike the private vehicle fleet, we find very small and effectively zero energy price elasticities for the public sector vehicle stock based on total fuel consumption and vehicle miles travel data from NTD. We generate fleet fuel economy for each urbanized area (UZA) in a year based on total fuel consumption (gasoline-equivalent) and total vehicle miles travelled. This variable, gallons per mile (GPM), is "realized" fleet fuel economy affected by both average fuel economy of all the buses and their individual utilizations. Table 1 presents the regression results from six different specifications where the dependent variable is $\ln (\mathrm{GPM})$ and the key explanatory variables are fuel prices. All the regressions include UZA fixed effects. All regressions include time trend and the last two only include observations with diesel accounting for more than $95 \%$ of the total energy consumption. Specifications 4 and 6 also include census

\footnotetext{
${ }^{3}$ The private fleet of heavy-duty trucks offers an alternative comparison group. The anecdotal evidence suggests that they respond to fuel price changes. For example, there is a recent trend of switching from diesel trucks to CNG trucks due to low natural gas prices. http://online.wsj.com/news/articles/SB100014240527023047076045774222192910235090

${ }^{4}$ Passenger vehicles are subject to Corporate Fuel Economy Standards (CAFE) but buses are not. However, the discrepancy in the growth rate is unlikely to be driven by CAFE standards alone. The standard for passenger cars was kept at 27.5 during 1997-2010 and jumped to 30.2 in 2011. For light trucks, the standard was a constant 20.7 during 1997 to 2004 and increased gradually to 24.2 in 2011.
} 
division-specific time trend. In all specifications, gasoline and CNG prices do not affect the fuel economy of the bus fleet. ${ }^{5}$

For-profit sellers of transit buses do not respond to rising gasoline prices by engaging in induced innovation. This finding stands in contrast with the fact that private vehicle suppliers respond to rising gasoline prices by offering more fuel-efficient vehicles (for long run trends see Knittel 2012). In Appendix Table 2, we document the fact that there is negative and statistically significant relationship between private vehicle's GPM and gas prices. As shown in Appendix Table 3 (whose specification is similar to the private vehicle regressions presented in Appendix Table 1), there is no statistically significant association between gasoline prices and the supply of more fuel-efficient buses.

To begin to understand why we observe these differences between the private transport capital stock and the public transport capital stock, it is relevant to note that the landscape of the U.S. bus market is dramatically different from the car market in that foreign producers are almost completely absent in the bus market while they represent more than half of the car market through both production in the U.S. and imports.

Table 2 lists the major bus manufacturers who sold buses in the U.S. between the years 1997 and 2011. Unlike the private vehicle market, buses produced by foreign bus makers account for less than 1.5 percent of the market. No foreign bus makers have production facilities in the U.S. so all of the foreign buses are imported. In addition, there are no Asian exports of buses to the U.S.

The bus fleets in Seoul and Tokyo are both more fuel efficient than in the U.S. The fleet fuel economy of buses in the U.S. was 3.54 miles per gallon (of gasoline-equivalent fuel) in 2011, compared with 4.74 in Tokyo that also operates a diesel-dominated fleet of about 1500 buses. ${ }^{6}$ In Seoul, the average fuel economy of 61 diesel buses was 5.05 and that of 7,469 CNG buses was

\footnotetext{
${ }^{5}$ Appendix Table 1 provides three additional regressions for different sub-samples and the finding of a zero energy price elasticities remains. The three subsamples focus on large UZAs, UZAs with fast population growth, and recession years, respectively.

${ }^{6}$ Tokyo Statistical Yearbook 2011: http://www.toukei.metro.tokyo.jp/tnenkan/2011/tn11q3e004.htm.
} 
4.04 in $2011 .^{7}$ While these durable buses are traded on the world market, U.S. transit agencies have chosen not to buy them. We will examine why this is the case.

\section{Bus Industry and Transit Bus Fleet Management}

We first discuss the industry background and then provide the institutional details that underline transit agents' decisions of bus fleet management.

\subsection{Industry Background}

In contrast with the passenger car market, foreign bus makers are by and large absent in the U.S. market. At the same time, U.S. bus makers are almost solely domestically oriented. While the Big Three (GM, Ford and Chrysler) have extensive network of sales and manufacturing plants in other countries, New Flyer, the largest bus maker in North America operates only in U.S. and Canada while Gillig, the second largest, concentrates on the U.S. market. ${ }^{8}$ On the other hand, major international bus makers such as Daimler Buses (owner of Mercedes-Benz buses) and Volvo have a significant presence in other markets including Asia, Europe and South America. Volvo has sales in 85 countries and production facilities in Europe, North America, South America, and Asia. The largest bus maker in China, King Long, sells buses in about 80 countries and regions. Although their international sales have been mostly in the developing world, they are poised to have a larger presence in Europe.

U.S. bus makers are much smaller in scale. The top two bus makers in the U.S. (New Flyer and Gillig) sell about 1000-1500 buses each year in the U.S. where the total annual sales are 4000 to 5000 buses. Major international bus makers such as Daimler and Volvo are an order of magnitude larger than U.S. bus makers: Daimler sells 30,000 to 40,000 buses and chassis and Volvo over 10,000 on a yearly basis. The top two bus makers in Japan (Hino and Fuso) each sell over 2000 buses domestically in a year out of over 9000 total buses sold in Japan. The largest bus maker in China, King Long, sold 29,000 buses in 2012.

\footnotetext{
${ }^{7}$ Based on a personal conversation with their personal at Seoul City Office.

${ }^{8}$ Both GM and Ford used to produce transit buses but sold or closed their production plants. Ford still produces chassis for shuttle buses.
} 
The U.S. bus production is concentrated in several states that are not known for automobile manufacturing. Among all the buses in service in 2011, over 24\% of them were produced in California while over 23\% were from Minnesota. Among the new buses produced in 2011, California produced 32\% them and Minnesota 24\%. ${ }^{9}$ Car manufacturing heavyweights such as Michigan, Ohio and Indiana only produced about 5\% of them. These shares are based on where the final assembly took place. Bus makers have very complex supply chains. For example, the fare system installed in New Flyer buses includes components produced by part suppliers in twelve states and the communication and the signal equipment from eighteen states.

\subsection{Background on Transit Fleet Management}

\section{The Agency's Objective}

A transit agent needs to meet the local peak demand that is affected by many factors including demographics and population size (Bar-Yoset et al. 2013). The Federal Transportation Administration (FTA) requires that the metro agencies create a "Fleet Management Plan" that explains how the metro agency will meet peak demand, and be prepared for unexpected demand shocks. Such agencies usually have to supply a level of services that is $20 \%$ greater than peak demand. Surplus capacity allows the metro to engage in maintenance and rebuilding and preventative maintenance while still providing service to riders. In addition to this stated objective, agencies have additional goals including creating local public sector jobs, coping with political pressure to award contracts to assembly plants in the same state. In addition, there is also pressure from constituents and environmental groups for cleaner buses such as hybrid or electric buses.

\section{The Budget Constraint}

Fleet management represents a set of interrelated decisions concerning the outflow of the old buses through scrappage and the inflow of new buses through procurement. In bus replacement decisions, the main tradeoff that the transit agencies face is between the upfront capital costs for new buses and the operating and maintenance costs for old buses. The

\footnotetext{
${ }^{9}$ New Flyer has two assembly plants in Minnesota while Gillig is based in California.
} 
availability of the federal funding eases the tight budget constraint that transit agencies often face. $^{10}$

The transit agency faces a budget constraint that varies over time depending on the inflow of various funding sources. Federal funding is an importance source of revenue and this funding is provided to match local funds. ${ }^{11}$ Federal funding for bus purchases mainly comes from two Federal Transit Administration (FTA) programs: the Urbanized Area Formula Program, and the transit capital investment program. The former is the primary federal funding source for capital costs and accounts for more than 80 percent of the federal funding. Funding is allocated based on legislative formulas: for urban areas with a population between 50,000 to 199,999, the formula is based on population and population density. ${ }^{12}$ For larger urban areas, it is based on a combination of factors including bus vehicle miles, passenger miles, population and population density.

The second program, the transit capital investment program provides supplemental funds for three categories of capital projects including replacement of buses and bus facilities. Funds are allocated on a discretionary basis each year and are primarily intended to support one-time or periodic capital needs left unmet by federal formula funding or by local or State funding sources. While the first source of funding is allocated lump-sum to the transit agencies who then can decide on how to allocate them to different capital projects, the second source of funding is earmarked for designated projects in the funding application.

One important requirement for obtaining federal funding is to "Buy America" and requires: (1) the vehicles must undergo final assembly in the U.S., and (2) at least $60 \%$ of the vehicle's components, by cost, must be manufactured in the United States. ${ }^{13}$ The prospect of receiving substantial matching funds from the "Buy American" would discourage transit

\footnotetext{
${ }^{10}$ In its 2012 Annual Report, New Flyer reports: “The Company’s principal customers are municipal and other local transit authorities that rely on funding from various levels of government to purchase heavy-duty transit buses. There can be no assurance that this funding will continue to be available at current levels, on the same terms or at all. Eighty percent of the total eligible funding for purchases of new heavy-duty transit buses in the United States is provided by the federal government through allocations to the FTA." (page 67 of 2012 Annual Report)

${ }^{11}$ The maximum level of subsidy is $80 \%$ of the capital expenditure on new buses. Rules for accessing federal funding require that a bus's total life expectancy should be at least twelve years.

${ }^{12}$ See http://www.fta.dot.gov/grants/13093_3561.html

${ }^{13}$ The location of headquarters or company offices is not a factor in the FTA's Buy America's regulation.
} 
agencies from purchasing foreign buses. This requirement constitutes an important entry barrier that foreign bus makers face to compete in the U.S. market. ${ }^{14}$ While foreign firms can setup a plant here (one of the five major bus makers was set up to assemble Hungarian buses), foreign firms are likely to lose their comparative advantage as they have to buy at least $60 \%$ of the materials from the U.S. and cannot rely on cheaper non-U.S labor.

Federal transfers to transit agencies increase during recession years. This fact helps to explain why private car sales are highly pro-cyclical, but bus purchases are not. This is due to the fact that federal funding accounts for up to $80 \%$ percent of transit agencies' capital expenditure. Anderson (1983) argues that local public transit agencies are well aware of these subsidies as they pursue their goals of bureaucratic growth. The U.S. government uses fiscal policy to stimulate the U.S. economy in times of recession. New public bus purchases provide a specific example of how federal government expenditure translates into increased investment in the capital stock. For example the American Recovery and Reinvestment Act of 2009 provided $\$ 6.9$ billion dollars for new equipment for public transportation projects.

Table 3 highlights how federal funding varies across years. The dependent variable in the four specifications measures the level or share of federal funding. Controlling for transit agency fixed effects, the regression coefficients indicate that relative to the omitted category of 1992, in the recession years (especially 2009), federal transfers for capital expenditure sharply increase. If transit agencies are gaming the business cycle, this could provide a partial explanation to the energy price inelasticity of bus purchases. Articles in the popular media have highlighted this point. The President of Gillig argues that the 2009 fiscal stimulus was crucial for propping up the demand during recessions and saving jobs in the industry. ${ }^{15}$

\section{The Role of the Clean Air Act on Bus Investment}

\footnotetext{
${ }^{14}$ The 2012 annual report New Flyers, a leading bus maker in North America explicitly mentions the Buy America as a significant entry barrier.

${ }^{15}$ The President of Gillig, Denny Howard said "I've been with Gillig for 32 years, so I've been watching the transit industry for decades. ... if the stimulus hadn't come through, the market would have dropped $40 \%$ to 3,000 buses a year for last year, this year, and at least through next year. That would have devastated our employees. I've heard the talk about the stimulus not creating enough jobs, but you never read a statistic about the number of jobs saved. ... I'd call the Recovery Act a success." (source http://fastlane.dot.gov/2010/04/american-busmaker-gillig-and-itsworkers-a-stimulus-success-story.html\#.UcRrYfmce9E)
} 
Environmental regulations often play a role in bus replacement and purchase decisions. There are three main types of buses in terms of fuel source: Diesel, CNG and hybrid buses. Diesel buses pollute more than other two types and are a significant contributor to local air pollution including particulate matter (PM) and ozone. Federal regulations from the Clean Air Act establish national ambient air quality standards for six pollutants including PM and ozone. State governments are responsible for meeting these standards and when in noncompliance, they may work with local governments to come up steps to comply with the standards. Transit agencies are often under pressure to reduce pollution from diesel buses by replacing them with less-polluting buses such as newer buses or CNG and hybrid buses. States such as California have passed stringent standards to reduce PM10 emissions from buses. ${ }^{16}$ As these standards grew stricter in the late 1990s, agencies increasingly purchased CNG buses that perform better on particulates but have worse fuel economy than diesel buses. For example, Los Angeles has retired all of its diesel buses and replaced them with CNG buses. ${ }^{17}$

\section{A Model of Transit Bus Procurement and Inventory Dynamics}

The scrappage of old buses and purchases of new buses can be integrated into a dynamic model of differentiated durable products demand. Each of the public transit systems at a point in time has a stock of buses it owns in inventory. It must choose whether to scrap them or not. In addition it chooses how many buses to buy and what types of buses to buy. The bus buyers know the price of each bus offered, the federal subsidies they can access, and the attributes bundled into each bus. The decisions are inherently dynamic due to the durability of buses. ${ }^{18}$ On the supply side, for-profit firms assemble buses with specific characteristics and sell them to the buyers. A resulting hedonic pricing gradient emerges and buyers sort and choose the "best bus" given their complex objective and their budget constraint defined over expenditures on labor, existing capital, new capital and energy.

\footnotetext{
${ }^{16}$ For specifics about California's metro bus rules for zero emissions buses see http://www.arb.ca.gov/msprog/bus/zbus/zbus.htm. California has long had the reputation as the nation's leader on implementing and enforcing vehicle emissions regulations (Kahn 1996).

${ }^{17}$ http://www.metro.net/news/simple_pr/Metro-receives-AQMDs-Clean-Air-Award-for-achieving/

${ }^{18}$ Unlike private cars, we have been unable to find any evidence of a liquid used bus market.
} 
The goal of this section is to shed light on the decision process of transit agencies as they decide their sequence of bus scrappage and procurement of new buses. We present a model of public transit's decision problem with respect to bus acquisitions. Before we proceed, we define our notation. Let

- $S_{t}$ be the amount of bus services (measured in total miles) provided at time $t$

- $L_{t}$ be the amount of labor employed at $t$

- $E_{t}$ be the amount of energy consumed at $t$

- $w_{t}$ be the wage of labor at $t$

- $P_{t}$ be the price of energy at $t$

- $i_{t}$ be the municipal bond interest rate at $t$

- $I_{t}$ be the cost of new equipment/buses

- $g_{t}$ be the percentage of $I_{t}$ subsidized at $t$

- $T_{t}$ the total tax revenue and income available to the transit authority at $t$

The agency wishes to produce services $S_{t}$ and has an infinite lifetime objective function discounted by $\beta$. The state space representation of the objective function is:

$$
\Phi_{t}=S_{t}+\beta \Phi_{t+1}
$$

Define maintenance costs $\mu$ as a function of bus mileage $M$ such that $\mu^{\prime}(M)>0$. Further define the level of services $S=S(L, A \mid V)$ where:

$$
A=\left\{\begin{array}{l}
a>0, \text { if } V(t) \neq V(t-1) \\
a=0, \text { if } V(t)=V(t-1)
\end{array}\right.
$$

denotes changes in the vehicle fleet. $V=\left\{V^{*}, V^{* *}\right\}$, where $V^{*}$ is the initial bus fleet and $V^{* *}$ is a new bus fleet such that the energy used by the fleet for any level of labor input $L$ is: $\alpha\left(L, V^{*}\right)=$ $\alpha\left(V^{*}\right) L>\alpha\left(V^{* *}\right) L=\alpha\left(L, V^{* *}\right)$.

Let $g_{t}=\left\{1\right.$ for all $V_{t}=V^{*}$; and 0 if no subsidy at $\mathrm{t} ; g^{* *}$ if subsidy at $t$ and $\left.V_{t}=V^{* *}\right\}$. Prob(subsidy at time $t)=\rho_{t}$ with $\rho_{t}>\beta^{k} \rho_{t+k}$ for all $k>0$. We first examine a world of constant prices and revenue to ease exposition: $I_{t}=I, w_{t}=w, i_{t}=i$, and $T_{t}=T$ for all $t$. We further assume that expected change in energy prices follows: $P_{t}=P_{1}>P_{0}$ for all $t>0$. 
A transit agent's problem at time $t$ is:

$$
\begin{gathered}
\operatorname{Max}_{\{L, V\}} E\left\{\Phi_{t}\right\}=S_{t}\left(L_{t}, V_{t} \mid V_{t-1}\right)+\beta E\left\{\Phi\left(V_{t+1}\right)\right\}, \text { s.t. } \\
T=w L_{t}+P \alpha\left(\mathrm{V}_{t}\right) L_{t}+i\left(1-g_{k}\right)+A+\mu\left(M_{t}\right) .
\end{gathered}
$$

The budget constraint is static in nature. The left-hand side, $T$, includes revenue from fares and funding from local, state and federal governments. The right-hand side is total expenditure including maintenance and operating costs (labor and fuel costs) and spending on new capital projects. If $V_{t-1}=V^{* *}$, then a maximum of (2) is achieved where

$$
L_{t}=\frac{T-i\left(1-g_{k}\right)-\mu\left(M_{t}\right)}{w+P \alpha\left(V^{* *}\right)} .
$$

where $k=t-i$ such that $V_{t} \neq V_{t-i}$ and $i>1$. If however, $V_{t-1}=V^{*}$ then the transit agency must decide whether or not to upgrade the fleet. That decision requires the evaluation of the following two terms:

$$
\begin{gathered}
\Phi^{* *}=\frac{\beta}{1-\beta} S_{t}\left(\frac{T-i\left(1-g_{t}\right)-\mu\left(M_{t}\right)}{w+P \alpha\left(V^{* *}\right)}, V^{* *}\right)+S_{t}\left(\frac{T-i\left(1-g_{t}\right)-a-\mu\left(M_{t}\right)}{w+P \alpha\left(V^{* *}\right)}, V^{* *}\right), \\
\Phi^{*}=S_{t}\left(\frac{T-\mu\left(M_{t}\right)}{w+P \alpha\left(V^{*}\right)}, V^{*}\right)+\beta \rho \Phi_{t+1}\left(. \mid V_{t}=V^{*}, g^{* *}\right)+\beta(1-\rho) \Phi_{t+1}\left(. \mid V_{t}=V^{*}, 0\right) .
\end{gathered}
$$

If $\Phi^{* *}>\Phi^{*}$, then $V_{t}=V^{* *}$, else $V_{t}=V^{*}$.

Proposition 1: If $V_{0}=V^{*}$, and at $t=0, \mathrm{~g}=1$, then there exists a sequence of $\left\{\rho, g^{*}, \mu\right\}$ such that $\Phi^{* *}<\Phi^{*}$, for all t.

The results implies that in the event government subsidies are sufficiently small, or disruption costs are sufficiently large relative to the energy savings, no purchase of new energy efficient buses will occur.

Proof: let $g^{*}=\varepsilon$, and $\mu=$ sufficiently small such that

$$
\Phi^{* * *} \approx S_{t}\left(\frac{T-i-a}{w+P_{t} \alpha\left(V^{* *}\right)}, V^{* *}\right) /(1-\beta)+S_{t}\left(\frac{T-i-a}{w+P_{t} \alpha\left(V^{* *}\right)}, V^{* *}\right)<\Phi^{* *}
$$


Let $\rho=\rho_{t}$ for all $t$. Then $\Phi^{* * *}<\Phi^{* *}<\Phi^{*}$ for all $t$ and there is a corner solution with no switching between $V^{*}$ and $V^{* *}$.

Proposition 2: If $V_{t}=V^{*}$, and no subsidy is offered at time 1, and the conditions of Proposition 1 do not hold, then there exists an $\left\{a, g^{* *}, \rho, \beta\right\}$ such that $V_{1}=V^{*}$, but $V_{k}=V^{* *}$ for some $k$. The proof is provided in the Web Appendix 3. This Proposition shows that a variable subsidy, say as contra-cyclical macroeconomic policy, could serve as such a trigger.

It is relevant to note that this model highlights a key option value component for delaying investment in new buses where the uncertainty is associated with the size of future federal government subsidies. This is particularly true if $\mu\left(M_{t}\right)$ increases rapidly enough as the existing fleet ages. If the probabilities $\left\{\rho_{t}\right\}$ change over time, then it would also be possible for a $\rho_{t}$ sufficiently low to make the value of $g^{* *}$ negligible and the energy benefit $\alpha\left(V^{* *}\right)$ could, if high enough, overcome the bureaucratic cost $A$. The proof is presented in the Web Appendix.

To summarize the implications of the model we consider four discrete changes: government transfers $g$, gas prices $P$, the quality of the bus fleet $\mu$, and the imposition of a "Buy America Mandate.”

a. A change in government transfers: In equations (5) and (6) $\Phi^{*}$ the value function for the no capital investment state is not a function of $g$ and $\Phi^{* *}$ is an increasing function of $g$. Since $g$, the level of government subsidies is unbounded, there exists a subsidy that would induce a fleet renewal decision at every point in time.

b. A change in gas prices will enter $\Phi^{*}$ and $\Phi^{* *}$ only through fuel usage $\alpha\left(V^{*}\right) L$ and $\alpha\left(V^{* *}\right) L$. Since $\alpha\left(V^{*}\right)>\alpha\left(V^{* *}\right)$ an increase in $P$ will increase $\Phi^{*}$ more than $\Phi^{* *}$ and make a fleet switch more likely. It should be noted however that as d. below argues, absent the "Buy America Mandate," it would make a fleet switch (to foreign produced buses) even more likely.

c. The quality of the bus fleet. As the fleet ages, maintenance costs increase. Therefore $\mu\left(M_{t}\right)$ by construction increases. For the fleet rollover decision this only affects $\Phi^{*}$ by decreasing the resources available for bus services. Therefore an aging fleet makes a fleet swap decision more attractive. 
d. The Buy America mandate, can be analyzed in our model by considering a third alternative bus type $V_{f}$ where $\alpha\left(V_{f}\right)<\alpha\left(V^{* *}\right)$ and $i_{f}<i$. In other words the buses are less expensive and they have better gas mileage. Then $\Phi^{f}<\Phi^{* *}+(1-\beta)^{-1}\left(i g_{k}\right)$. In other words, absent the subsidy, the bus company would choose the foreign manufacturer rather than the domestic manufacturer if a fleet change was indicated. The Buy America mandate is then binding when $\Phi^{f}>\Phi^{* *}$ as the bus authority only receives the subsidy if they buy the domestic product. Thus the Buy America mandate acts as a tariff on foreign buses such that the fuel economy gained is outweighed by the net effective price to the purchaser.

\section{Empirical Analysis of Fleet Management Decisions}

In this section, we investigate the fleet management decisions of transit agencies and study various factors underlying these decisions. We first present our data. We then examine the outflow of the buses through scrappage and after that, the investment in new buses through procurement. This analysis allows us to study how the quantity and quality of public capital evolves over time.

\subsection{Data}

The major data source for our analysis is the National Transit Database (NTD). This provides us with detailed transit data from transit agencies each year from 1997 to 2011 . The NTD was established by Congress to gather and distribute information and statistics on the transit systems in the country. Currently, over 660 transit agencies in urban areas, who are recipients or beneficiaries of federal transit grants, report to the NTD.

For each transit agency in each year, the NTD provides data on the total count of active buses, their model year distribution, total miles travelled in previous years by bus system/make/model year. For each bus, we also observe the bus manufacturer's name and fuel type. Table 4 present summary statistics of the bus inventory data. Since many of our explanatory variables are at the UZA level, we aggregate data from transit agencies to Urbanized Areas (UZA) which could contain multiple transit agencies. The unit of observation is a vintage- 
model by UZA-year. The average number of buses per vintage-model is 33 with the maximum being 763. The average scrappage rate is 6 percent and the average bus age is 8.27 with about 7 percent of them being new buses. Figure 2 presents the distribution of scrappage rate and miles traveled by age. Among all buses, 87 percent are diesel buses while 10 percent are compressed natural gas $(\mathrm{CNG})$ buses. The vast majority of the buses (98 percent) are by domestic producers (or producers with plants in the U.S.). About 11 percent of the buses are produced in the same state as the buyer.

The NTD also provides total energy consumption across all of the buses in the fleet broken out into twelve categories such as gasoline, diesel, CNG, liquefied natural gas (LNG) etc. We use these energy consumption data and standard index weights to compute total gasolineequivalent consumption for each bus system in each year. ${ }^{19}$ A separate NTD file provides information on annual operating expenditure and capital expenditure by public transit system/year. The NTD does not provide information on the purchase price of each bus and we could not find systematic price information anywhere, likely due to the fact that bus makers and transit agencies negotiate one to one on transactions. Instead, annual data are provided on total expenditure on the new capital stock and the count of new buses purchased of each make. While the NTD names the bus makes, it provides few details about the physical attributes of the buses except for its occupant capacity and length.

We also collect state and county demographic (state population and gross state product per capita) and environmental variables (county PM2.5 and Ozone nonattainment status). ${ }^{20} \mathrm{We}$ collect gasoline prices at the city level from Cost of Living Index database. Although diesel is the major fuel used by public buses, we use gasoline prices for our analysis below. We are not aware of comprehensive city-level diesel prices and state-level coverage from the Energy Information Administration is not complete as well. In addition, diesel and gasoline prices are highly correlated as both are derived from petroleum and subject to similar market forces: the correlation coefficient between gasoline price and diesel prices for nine states available from the

\footnotetext{
${ }^{19}$ Our data sources for these emissions factors are Knittel (2012) and the US Energy Information Administration (http://www.eia.gov/oiaf/1605/coefficients.html\#tbl2).

${ }^{20} \mathrm{http}: / /$ epa.gov/airquality/greenbk/
} 
Energy information administration (EIA) is 0.98 between 1997 and 2011 . We collect annual state-level natural gas vehicle fuel prices from the EIA.

\subsection{Bus Scrappage}

We examine how transit agencies make scrappage decisions taking into account various factors and constraints discussed above such as maintenance costs, fuel costs, federal transfers and environmental regulations. Our main goal here is to understand the importance of these various factors in transit agencies' decisions and we do not attempt to estimate a dynamic model. In contrast with the single-agent dynamic model estimated in Rust (1987), a formal dynamic stochastic model of transit agency decisions would be challenging to set up and estimate for several reasons. ${ }^{21}$

First, the objective function of a transit agency is unlikely to be strictly profit optimization as such an agency may prioritize additional factors such as creating local employment and engaging in bureaucratic growth (Anderson 1983). In addition, agencies also face multiple constraints as we discussed above. Second, each transit agency owns a large number of buses with different vintage and cumulative miles and the decision should be made simultaneously over the whole fleet. Third, scrappage decisions and purchase decisions are jointly made. Purchase decisions themselves are multi-dimensional in that they are multiple bus makers and different fuel types as well as the fact they may buy from multiple makers (for different units) at the same time.

Denote $j$ as vintage-model (e.g., 2000 Gillig Phantom) and $c$ as UZA (city) and $t$ as year. We estimate the following equation:

$$
R_{j c t}=\alpha_{1} A g e_{j c t}+\alpha_{2} \text { Miles }_{j c t}+\alpha_{3} N A_{c t}+\alpha_{4} F e d_{c t}+X_{j c t} \beta+\mu_{t}+\eta_{j c}+\varepsilon_{j c t},
$$

where the dependent variable is the scrappage rate defined as the change in the number of buses of a vintage model in a fleet from year $t-1$ to year $t$ divided by the number of buses in $t-1$. We use vehicle age and cumulative mileage to control for (expected) maintenance costs. Given that

\footnotetext{
${ }^{21}$ Rust (1987) studies the optimal timing of replacing a bus engine by the bus manager weighing the upfront replacement costs against future maintenance costs.
} 
maintenance costs are likely to be a convex function of these variables as reflected in Figure 2, we include polynomials of age and mileage in the regression as well.

To examine if transit authorizes respond to environmental regulations by retiring their diesel buses earlier than otherwise, we include indicators of a county's (one-year lagged) nonattainment status in PM2.5 and Ozone. The dummy variable $N A_{c t}$ is one for county $c$ in year $t$ if there is violation of federal standards in either PM2.5 or Ozone in year $t-1$. Regular diesel buses tend to emit more pollutants than $\mathrm{CNG}$ and hybrid buses and these pollutants can lead to high PM2.5 and Ozone concentrations. In addition, earlier vintages of diesel and CNG buses are more polluting than newer vintages due to improvement in emission-reduction technology and the tightening of emission standards over time. ${ }^{22}$ Since the regulations will mainly affect older buses in scrappage decisions if at all, we interact the non-attainment status dummy variable with a dummy variable for vehicles ten years old and above.

As we discussed above, federal funding accounts for a significant share of total capital expenditure of transit agencies and it often increases during economic recessions due to stimulus measures. Increased federal funding will relax the tight budget constraint many transit agencies face and expedite the scrappage of old buses. In one of the specifications we present below, we include $\mathrm{Fed}_{c t}$, the per capita federal funding for capital expenditure (in logs).

The regression also includes other control variables in $X_{j c t}$ such as vintages to reflect changes in production technology over time, gasoline prices to reflect changes in operating expenses, and variables that capture demographic shifts and income growth. We include population growth and area growth in the UZA to control for demand growth for bus services which may affect scrappage decisions.

We control for time-varying unobservables $\left(\mu_{t}\right)$ and UZA-vintage-model level $\left(\eta_{j c}\right)$. In an OLS framework, we can control for both types of un-observables using fixed effects. However, given that the dependent variable ranges from zero to one, we use Tobit regressions to estimate the parameters. Due to the incidental parameters problem, we use random effects to

\footnotetext{
${ }^{22}$ According to the EPA, buses that meet EPA's 2010 standards emit 95 percent less pollution than pre-2007 vehicles and are 60 times cleaner than pre-1991 buses.
} 
control for un-observables $\eta_{j c}$ in Tobit regressions. We add manufacturer dummies and state dummies in random effects Tobit regressions as our preferred model to control for unobservables at the make and state level that might be correlated with the explanatory variables.

Table 5 presents estimation results for five specifications. Given the small number of hybrid buses and the fact that $90 \%$ of them are five years old and younger, we focus on diesel and CNG buses in these regressions. The first column is from OLS where we include year fixed effects and UZA-vintage-model fixed effects as specified in equation (1). The second column presents results from a Tobit model where we include year fixed effects, manufacturer fixed effects and state fixed effects but do not control for UZA-vintage-model fixed effects. The third and fourth columns report random effects Tobit regressions which control for UZA-vintagemodel un-observables using a random effects specification. The third column does not include state fixed effects while the fourth does. The fifth column adds the federal funding variable which one might worry being endogenous as we noted above. We focus on the results from the fourth column, our preferred specification, noting the results are generally robust across specifications where unobservable factors are controlled in different ways.

Several findings emerge. First, bus age and cumulative miles are both highly statistically significant determinants of scrappage rates. Within the range of vehicle age (1 to 30 ) and cumulative miles ( 0 to 230,000 miles), the effects of age and miles on scrappage are both positive. For a 15 -year old bus, the scrappage rate increases by 10 percentage points when it ages by one year. In terms of the effect of vehicle miles, the scrappage rate increases by 2 percentage points when the vehicle miles grow from 200,000 to 300,000 .

Second, the positive coefficient estimate on county nonattainment status (for buses age 10 and above) suggests that PM2.5 and Ozone regulations affect bus scrappage decisions. County non-attainment for either PM2.5 or Ozone leads to faster retirement of old buses. The magnitude of the effect is similar to the difference in scrappage rate between a 19-year old bus and a 20 -year old bus. This finding suggests that transit agencies respond to federal regulations.

Third, gasoline prices do not affect scrappage decisions: the coefficient estimates on gasoline price variables are small in magnitude and not statistically significant. This finding is consistent with the results reported in Table 1 that gasoline prices do not affect fleet fuel 
economy of buses. But it is in contrast with the finding for the scrappage of passenger cars (Li, Timmins and von Haefen 2009; Jacobsen and van Benthem 2013). ${ }^{23}$

Lastly, the increase in federal funding is associated with earlier retirement of old buses as transit agencies take advantage of these funding to purchase new buses. We recognize the potential endogeneity of including this federal funding variable. ${ }^{24}$ Adding the federal funding variable do not change the coefficient estimates on other variables in any meaningful way except for gross state product per capita.

\subsection{Bus Procurement}

In this section, we examine the factors underlying bus procurement decisions. We focus on two decision margins: how many to buy from different makes (choices over make), and how many to buy for each fuel type (choices over fuel type). The choice set of makes includes ten of the largest domestic makes, foreign make (lumping all foreign makes into one), and small make (lumping all other makes into one). The choice set of fuel types includes three: diesel, natural gas, and hybrid. In practice, these two decisions are likely to be made jointly and can be potentially modeled simultaneously in a unified framework such as a discrete choice model in a product characteristics space as in Berry, Levinsohn and Pakes (1995) where make and fuel type will be characteristics of each choice (i.e., bus model). A technical challenge in estimating such a discrete choice problem is how to allow purchases of multiple units of each model as well as from multiple makes. Allowing for such possibilities would make the discrete choice problem

\footnotetext{
${ }^{23}$ In the regressions, we use gasoline prices in the current year to capture expected gasoline prices following the literature, which amounts to a random walk assumption. Alternatively, we could use the gasoline prices in the next year following a perfect foresight assumption. But the qualitative conclusion does not change for this scrappage equation and the same holds for the purchase equations examined below.

${ }^{24} \mathrm{We}$ argue that the correlation between this variable and the error term is likely to be small. First, as we discussed above, the majority of the federal funding comes from the formula program that allocates funds based on observed variables such as population from the census. To the extent some of these variables affect scrappage decisions, they are controlled either directly such as the area's population growth or indirectly through fixed effects. Second, the other source of funding is discretionary and is allocated once applications from transit agencies are approved. This portion of funding might be more likely to be correlated with unobserved factors. Due to the endogeneity concern of this variable, we include it only in the last specification. We have tried using population growth and area growth as IVs for federal funding in the OLS framework (the first specification) but they prove to be only weakly correlated with federal funding.
} 
an extremely high dimensional decision. ${ }^{25}$ We examine the decision margins over bus make and fuel type separately. This allows us to look at different factors affecting the two margins in a practical and parsimonious way. ${ }^{26}$

In addition, we do not jointly model the purchase decision and the utilization decision, unlike Dubin and McFadden (1984). As we discussed above, transit agencies are required to meet peak demand and in the short run, the changes in bus routes are small over time. We include population, income and state-specific time trend to control for changes in travel demand. The key results are robust to the exclusion of these variables. ${ }^{27}$

\subsubsection{Purchase Decisions over Bus Make}

To study choices over the demand for a bus make, we estimate the following equation.

$$
S_{k c t}=\alpha_{1} L_{k c}+\alpha_{2} F_{k t} * D_{k c}+\alpha_{3} B_{k c t}+X_{c t} \beta+\mu_{t}+\lambda_{k}+\eta_{c k}+\varepsilon_{k c t},
$$

where the dependent variable, $S_{k c t}$, is the share of new buses of make $k$ among total new buses purchased by UZA $c$ in year $t . L_{k c}$ is a dummy variable being 1 for make $k$ in UZA $c$ if the bus manufacturer has production facility in the state where UZA $c$ is. A positive coefficient on this variable would suggest local favoritism. We use local favoritism as a broad term and it may be

\footnotetext{
${ }^{25}$ Studies such as Berry, Levinsohn and Pakes $(1995,2002)$ and Goldberg (1995) have formulated a demand system for cars based on a utility maximization framework over the product space. The multiple constraints and objectives discussed above make bus purchase decisions more complicated. In addition, the lack of data on bus characteristics and multi-unit demand make the framework infeasible in our context.

${ }^{26}$ As a robustness check on whether much is lost by modeling the make and fuel type decisions separately, we also estimate a multinomial logit model with random effects. The choice set includes all available combinations of 11 makes and three fuel types (such as a Gillig diesel bus). There are 20 choices in 1997 and 24 in 2011 due to the fact that hybrid buses not all bus makers produce hybrid buses and hybrid buses started to appear after 2005. To generate multinomial outcomes (a vector with one element being one and the rest being zero), we assign one to the choice with the largest purchase and zero otherwise. Among 2280 purchase incidences in our data, two-thirds are single purchases in a UZA-year. While circumventing the problem of multiple choices, this simplification treats the other (smaller) purchase incidences to be non-purchase. Appendix Table 4 presents the estimation results for several different specifications and these results are qualitatively the same with those from the separate modeling method to be discussed below.

${ }^{27}$ We note that the purchase decisions are not jointly modeled with scrappage decisions. Although the correlation between these two types of decisions would be interesting to study and may affect the efficiency of the estimation, we choose not to model them jointly for parsimony and tractability, recognizing that ignoring it is unlikely to lead to bias in our estimates.
} 
due to many different reasons such as the concern for the employment in the state and better relationships between the transit agencies and bus makers due to closer proximity. To examine the effect of federal funding, we interact the share of federal funding $F_{k t}$ with the domestic dummy variable $D_{k c}$ which is one for domestically produced buses. Due to the potential concern regarding the endogeneity of the federal funding variable, we only include it in one of many specifications. $B_{j k t}$ is the percent of buses from the same make among the existing buses, capturing the cost savings in spare parts stock when all buses are from the same make.

We include other control variables in $X_{c t}$ such as the average age of the bus fleet and variables that capture a UZA's population change and income growth. $\mu_{t}$ captures time fixed effects while $\lambda_{k}$ capture bus make fixed effects. $\eta_{c k}$ controls for time-invariant UZA-make unobservables that capture special relationship between a UZA-make pair.

The estimation strategy is similar to our approach in estimating the scrappage equation. The dependent variable ranges from zero to one so we use Tobit regressions. In our preferred random effects Tobit model, we use random effects to capture UZA-make un-observables and include state fixed effects. The estimation results are presented in Table 6 . The first column is from OLS where we include year fixed effects, make fixed effects and UZA fixed effects. Given that about 90 percent of the observations are left-censored at zero, we expect a large bias from OLS. The other three columns are all from Tobit regressions where the two-sided censoring is taken into account. The second column is from a Tobit where we have included year fixed effects, make fixed effects and state fixed effects but do not control for UZA-make unobservables. The third and fourth columns are from random effects Tobit regressions which control for UZA-make un-observables using random effects. The third column does not include state fixed effects while the fourth does. The last specification adds the interaction term between federal funding and domestic bus dummy.

As expected given the heavy censoring of the data, the OLS coefficient estimates are much smaller than those from Tobit regressions. The estimates are generally the same across the four specifications using Tobit. There are several important findings from column (4), our preferred model. First, the positive and significant coefficient estimate on the local dummy suggests that transit agencies prefer buses produced within their own state. As we discussed 
above, this is likely due to many factors such as considerations of the local employment effects and special relationships between transit agents and bus makers. The coefficient estimate of 0.457 on the local dummy is economically significant; the mean of the dependent variable (the share of each bus make) is 0.68 for 2,287 non-zero shares.

Second, the coefficient estimate of 0.426 on the interaction between pro-union state and domestic bus dummy implies that pro-union states have a preference for domestic buses (relative to other states). ${ }^{28}$ The estimation results (marginally insignificant) provide some evidence that decisions of transit agencies are subject to union influences. Protecting domestic employment is one key argument used for the Buy American mandate. Labor is a significant component of bus assembly as well as manufacturing at the part suppliers. According to the 2011 annual report of New Flyer, labor at the assembly plants accounts for $9 \%$ of the bus assembly while materials account for $71 \%$. Paul Saubry, the CEO of New Flyer suggests that the bus assembly creates one to two jobs per bus while one bus is associated with four to five jobs for bus parts suppliers.

Third, transit agencies prefer to purchase buses of the same make they purchased before. A typical - public transit agency has built up both physical capital and human capital that is bus brand specific. They have invested in customizing their maintenance facilities to work with a specific type of bus and their mechanics have been trained to work on such buses. In addition, they have invested in a spare parts inventory that is customized for specific buses. ${ }^{29}$ These factors are likely to cause a lock-in effect such that bus buyers tend to buy from the same bus sellers. The bus companies also explicitly seek to build relationships with transit agency officials in order to generate repeat business. ${ }^{30}$

Lastly, based on the final specification, transit agencies favor domestically produced buses especially when they have access to more federal funding. This is likely due to the "Buy

\footnotetext{
${ }^{28}$ We define those states that are not Right to Work states to be "pro-union".

${ }^{29}$ For example, the diesel bus has no spark ignition system but CNG vehicles do. The issue of fleet standardization often dictates purchase decisions of airlines. For example, Southwest airlines operate only Boeing $737 \mathrm{~s}$. As the largest operator of 737 worldwide, they are able to press Boeing to produce more fuel efficient models to better meet their needs.

${ }^{30}$ In its 2012 Annual report, New Flyer reports; “Ongoing dialogue with existing customers, enhanced by a service or support relationship, assists in identifying opportunities for new business. Over the last five years, approximately $90 \%$ of buses produced by the Company were for customers who had purchased buses from the Company in the preceding five years."
} 
America" mandate as we discussed above. This restriction on imports, similar to import quotas, could have important implications on the industry for example, by reducing incentives for firms to innovate and to improve efficiency (Krueger 1974, Lenway et al. 1996). The domestic bus makers stand to gain at the expense of social welfare due to the misallocation of resources. Lenway et al. (1996) find empirical evidence on that trade protectionism leads to more lobbying efforts among less productive and innovate firms and higher return to those firms in the American Steel industry. ${ }^{31}$ We believe that this mandate could be an important reason behind the lack of international competition and high prices of American made buses.

We note that we have controlled for UZA-make random effects in the last three specifications. The purpose is to control for unobserved factors that contribute to the likelihood of a repeat purchase of the same make by a transit agency. The second specification does not control for them. Although the coefficient estimates on the percent of the old buses from the same make becomes smaller in the last three specifications as expected if un-observables exist, they are still significant and large in magnitude. ${ }^{32}$

Ideally, the identification of local favoritism (the coefficient on the local dummy) should come from exogenous shocks that re-locate a manufacturing plant from one state to another. However, we do not observe plant relocation during our data period. Therefore, the local dummy variable is not time-varying for a given UZA-make pair. We cannot include UZA-make fixed effects in the model to control for time-invariant un-observables (other than the local relationship). Instead, we use random effects at the UZA-make level in the Tobit model to control for the un-observables. The difference between columns (2) and (4) is that column 2 does not include random effects at the UZA-make level but column (4) does. The coefficient estimates across these two specifications are generally quite close and this gives us some confidence that the results are not driven by UZA-make un-observables (such as transit agencies in the same states likes the size or color of the buses made in the state) that are not related to the broad definition of local favoritism.

\footnotetext{
${ }^{31}$ Based on data from www.opensecrets.org, none of the domestic bus makers are contributing to Political Action Committee campaigns. "Buy American" applies to broad purchases of using federal funding and domestic bus buyers are just small stakeholders in the broad context.

${ }^{32}$ The (fleet-size) weighted average of the percent of old buses from the same make is 0.30 .
} 


\subsubsection{Purchase Decisions over Fuel Type}

We now turn to the decisions over the fuel type of the buses and we focus on three types: diesel, CNG and hybrid. Buses of different fuel type differ in upfront purchases costs, fuel costs during operation and with respect to their emissions levels. A standard 40-foot transit bus costs approximately $\$ 300,000$ while $\mathrm{CNG}$ buses cost about $\$ 30,000$ more. A hybrid bus costs between $\$ 450,000$ and $\$ 550,000$. Among the three types, hybrid buses have the best fuel efficiency (25$50 \%$ better than diesel buses) while CNG buses have the lowest (about 25\% lower than diesel buses). In addition, CNG buses require expensive special re-fueling infrastructure and maintenance facilities compared to diesel buses, which are the traditional transit bus choices. In terms of environmental performance, hybrid buses rank the best while diesel buses the worst, especially diesel buses manufactured before 2007. Emissions standard for diesel engines in buses have tightened quite aggressively over time and the difference in emission levels between buses of different fuel type have narrowed.

This section examines how transit agencies consider these tradeoffs by estimating the following equation:

$$
S_{f c t}=N A_{c t} F_{f} \alpha+F P_{c t} F_{f} \gamma+X_{f c t} \beta+\mu_{t}+\lambda_{f}+\eta_{c f}+\varepsilon_{f c t},
$$

where the dependent variable, $S_{f c t}$, is the share of new buses of fuel type $f$ among total new buses purchased by UZA $c$ in year $t . N A_{c t}$ is equal to one if the jurisdiction is a non-attainment area in either PM2.5 or Ozone during the last year. $F_{f}$ is a vector of three dummies variables corresponding to three fuel types. The interactions of non-attainment status and fuel type dummies examine if fuel type choices are affected by environmental regulations. $F P_{c t}$ is defined as fuel (gasoline) prices and it interacts with fuel type dummies, $F_{f}$, if (expected) fuel expenses are taken into account in purchase decisions. $X_{f c t}$ is a vector including all other control variables.

Similar to equation (10), we control for UZA-invariant un-observables over time $\mu_{t}$, fuel type fixed effects $\lambda_{f}$ and time-invariant UZA-fuel type un-observables $\eta_{c f}$ that capture special preferences a UZA may have for buses of fuel type $f$ (e.g., a UZA may prefer CNG buses because they have easy access to natural gas pipelines or re-fueling stations). 
The dependent variable ranges from zero to one so our estimation strategy follows those for equation (10) closely as well. We use a random effects Tobit regression as the preferred specification where we control for year fixed effects, fuel type fixed effects, state fixed effects, and random effects at the UZA-fuel type level. Table 7 presents regression results for five specifications. The first column is from OLS and the other four columns are from Tobit regressions. The second column does not control for UZA-fuel type un-observables while the last three columns do. Column (3) does not control for state fixed effect and columns (4) and (5) do. In column (5), we add the interaction term between federal funding and hybrid bus dummy.

The estimation results are very similar in columns (3) to (5) and we focus our discussion on those from columns (4). First, non-attainment status in PM2.5 or Ozone leads to less demand for diesel buses and more for CNG buses. The coefficient estimate on the interaction between non-attainment status and diesel bus is -0.576 while that on the interaction between nonattainment status and CNG bus is 0.579 . Both are large in magnitude: the average share by fuel type is 0.89 among 1315 non-zero observations and it is 0.43 among all 3479 observations. The coefficient estimate on the interaction between non-attainment status and hybrid dummy is not statistically significant which could partly be a reflection of the fact that hybrid buses account for only five percent of the new buses and their purchase decision could be subject to more idiosyncratic factors that we do not observe.

Second, fuel prices have no statistically significant effects on fuel type decisions although the signs of the coefficient estimates are intuitive except that on the interaction between gasoline price and $\mathrm{CNG}$ bus dummy. This result is consistent with the finding that scrappage decisions are not affected by fuel prices. Both of them confirm our motivating fact that fuel efficiency of the bus fleet is not responsive to fuel prices.

Third, based on the last specification, demand for hybrid buses is positively affected by federal funding. Hybrid buses are at least 50 percent more expensive than diesel counterparts and the upfront purchase costs could be a hurdle for their adoption especially under tight financial conditions. Additional capital funding could relax the constraint and lead to more purchases of this type of bus. 


\section{Discussion}

As we discussed above, federal funding is an important source of capital expenditure and can cover up to $80 \%$ of the capital costs of buses. The Buy America mandate combined with the federal funding essentially plays the role of a subsidy for purchasing domestic buses. Domestic bus suppliers appear to gain the bulk of the economic incidence of this subsidy.

The bus market can be characterized as a differentiated product oligopoly as in the automobile industry. Buses are differentiated among many dimensions such as floor height, fuel type, seating capacity and size. The bus market is more concentrated with the top five makers accounting for over $75 \%$ of the U.S. market. In addition, as we documented, the fleet standardization is an important consideration in bus purchases. On average a transit agency purchases $52.5 \%$ of its buses from its largest bus supplier and $24 \%$ of its buses from its second largest bus supplier based on bus purchased from 1997 to 2011. For comparison, the top two U.S. bus makers, Gillig commanded $25 \%$ of the market share while New Flyer $22 \%$ during this same period. These comparisons highlight the lock-in effect, which would increase the bargaining power of the bus suppliers. Union work rules may also re-enforce these lock-in effects as bus drivers may not want to learn how to drive many different types of buses. In addition, the lock-in effects could also reduce transit agencies demand responses to fuel prices because of limited varieties offered by each bus maker. For example, Gillig and New Flyer each only have two product lines currently available, with each product line offering two or three choices of length.

Second, the subsidy could be an important barrier to entry and it is cited as so in the annual report of New Flyer. The Buy American mandate requires 60 percent minimum domestic content and U.S. final assembly. So although foreign bus makers can set up bus assembly plants as automobile manufacturers do in the U.S., the requirements could greatly reduce their advantage for example in lower labor, economies of scale, or material costs. ${ }^{33}$ The lack of competition from abroad may cause inefficiency in production due to the lack of an incentive to innovate. Even if domestic bus buyers demand more fuel-efficient vehicles, if their total demand

\footnotetext{
${ }^{33}$ North American Bus Industries (NABI) was originally setup in 1992 to assemble unfinished buses from a sister company in Hungary as a way to allow compliance with the Buy America mandate. In early 2013, NABI discontinued the practice and relegate all manufacturing and final assembly activities in the US. The company has since acquired by New Flyer Industries.
} 
for such vehicles is low this may not provide sufficient revenue for domestic suppliers to cover the fixed costs of developing new varieties (Acemoglu and Linn 2004).

When the price premium of making energy efficient buses in the U.S. is sufficiently large, one can expect that a foreign manufacturer may open a U.S. factory. In 2013, BYD, a major producer of electric cars and buses in China, opened a manufacturing site in California and signed contracts with the cities of Los Angeles and Long Beach to sell over100 electric buses to their respective public transit agencies. The electric buses sell at about $\$ 800,000$ per unit, more than twice as expensive as a diesel bus.

The subsidy on domestic buses and the lack of international competition imply that U.S. tax payers face a higher price for urban bus services and U.S. owners of the domestic firms that produce the buses gain some monopoly rents. Based on NTD data from 1997 to 2011, the average price for a U.S. public transit bus (in year 2011 dollars) was $\$ 309,000$ with the $10^{\text {th }}$ percentile of the empirical distribution being $\$ 104,000$ and the $90^{\text {th }}$ percentile at $\$ 497,000$. While it is difficult to construct a hedonic bus price regression where we control for key public transit bus characteristics including quality, our research suggests that measured in comparable units, buses in Tokyo and Seoul are half the price of U.S. buses and buses produced in China are even cheaper. ${ }^{34}$ While cynics might question the quality of China's buses, it is notable that wealthy and well governed Singapore is importing buses from China. ${ }^{35}$ In addition, different transit agencies may have different preferences or need for quality (such as air conditioning) and face different level of budget tightness, therefore, one should not simply rule out Chinese buses as preferred buses by all transit agencies.

High domestic costs for buses would result in fewer buses being purchased due to capital constraints and this hinders the economics of scale that is vital for determining the quality of

\footnotetext{
${ }^{34}$ A regular 40 -feet diesel bus costs about $\$ 300,000$ in the U.S. while a hybrid bus costs about $\$ 450,000$ to $\$ 550,000$. According to the 2011 annual report of New Flyer, the largest bus maker in North America, the average selling price per bus is about $\$ 450,000$ where the composition of buses sold are $44 \%$ diesel, $43 \%$ hybrid and $13 \%$ CNG buses. According to Volvo's 2011 annual report, Volvo sold 12,786 buses with a total revenue of 22.3 billion SEK, implying an average price of about $\$ 272,000$ per bus.

${ }^{35}$ Transportation costs of shipping international buses cannot explain why the United States imports cars but not buses. Transit buses weigh from 25,000 to 40,000 pounds while a passenger vehicle typically weighs from 2,000 to 5,000 pounds. Given the price of a typical transit bus is about 10 times of a passenger vehicle, the value per unit of weight is not necessarily smaller for buses.
} 
public transit such as service frequency and coverage (Morhing 1972). Although transit agencies are required to meet demand, demand is endogenous to the level of service. Higher costs could lead to fewer buses purchased and a lower level of service, which would depress demand and hinder scale economies.

Today, U.S. public transit agencies are offered deep subsidies for purchasing domestic buses. If in addition they could import buses, they would have access to a greater menu of differentiated products at lower prices. This would lead to a higher quality of service provision (e.g., better service frequency and coverage) which could induce urbanites to substitute from private vehicles to buses.

\section{Conclusion}

Public buses are a major component of the public transit system and represent a multibillion dollar investment. Motivated by the finding that the fleet fuel economy of public buses does not respond to fuel price, this paper has used several data sets to study the demand and supply for transit buses over the years 1997 to 2011.

Our analysis suggests that the non-responsiveness of bus fleet fuel economy to fuel prices reflects several features of the bus market. On the demand side, non-profit transit agencies purchase more expensive buses relying extensively on federal subsidies. These subsidies are provided with "strings attached" known as the Buy American mandate. In addition, their purchase decisions are influenced by other considerations including environmental regulations, local employment, and commonality with their existing bus fleet. On the supply side, a handful of domestic bus makers account for the vast majority of the market share and imports are nearly non-existent. The domestic bus makers supply a small number of differentiated bus models. The lack of competition could retard incentives to develop more fuel-efficient buses. We argue that demand-side constraints dampen the effect of fuel prices on fleet fuel economy while the nature of the supply side re-enforces the non-responsiveness.

The Buy America mandate serves as an important entry barrier to the U.S. bus market. In the resulting hedonic equilibrium, U.S. public transit agencies pay more for buses than they would have if there had been free international trade in buses. Such bus sellers can raise the 
price of their buses above world prices because the binding Buy America subsidy means that bus buyers have very little incentive to consider cheaper international exports. The nature of a differentiated product oligopoly of the bus market exacerbates the positive effect of subsidies on bus prices. High bus prices in turn imply that the quality of bus services (e.g., coverage across space and time) and the demand for public transit could be negatively affected.

Private vehicle usage contributes to local air pollution, greenhouse gas production and to the urban traffic congestion (Anderson 2013, Parry and Small 2005, 2009, Meyer, Kain and Wohl 1965). Due to their economy of scale, buses could produce lower levels of local air pollution and greenhouse gas emissions per passenger mile. Improvements in the quality of public transit would reduce all three of those externalities because many private vehicle users would substitute to the cheaper public transit alternative. While buses offer social benefits over cars, the slow speed of urban buses and the waiting times lead many richer households to seek the convenience of private vehicles (Glaeser, Kahn and Rappaport 2008). If U.S. cities offered the quality of the public bus fleet that other cities such as Singapore offer, then voter opposition to introducing road pricing (and hence increasing urban traffic speeds) would be likely to decline (Harsman and Quigley 2010). 


\section{References}

Acemoglu, Daron, and Joshua Linn (2004).. "Market size in innovation: theory and evidence from the pharmaceutical industry." The Quarterly Journal of Economics 119, no. 3: 1049-1090.

Anderson, Michael L. Subways, strikes, and slowdowns: the impacts of public transit on traffic congestion. American Economic Review. forthcoming

Anderson, Shirley C (1983). The effect of government ownership and subsidy on performance: Evidence from the bus transit industry. Transportation Research Part A, 17(3): 191-200.

Bar-Yosef, Asaf, Karel Martens, and Itzhak Benenson (2013). A model of the vicious cycle of a bus line. Transportation Research Part B, 54: 37-50.

Berry, Steven, James Levinsohn, and Ariel Pakes (1995). Automobile prices in market equilibrium. Econometrica, 63(4): 841-890.

Berry, Steven, James Levinsohn, and Ariel Pakes (2004). Differentiated products demand systems from a combination of micro and macro data: The new car market. Journal of Political Economy, 112(1): 68-105.

Boudart, Jesse, and Miguel Figliozzi (2012). A Study of the Key Variables Affecting Bus Replacement Age Decisions and Total Costs 2. Analysis 18: 19.

Dubin, Jeffrey, and Daniel McFadden (1984). An Econometric Analysis of Residential Electric Appliance Holdings and Consumption. Econometrica, 52: 345-362.

Gillingham, Kenneth (2013), Identifying the Elasticity of Driving: Evidence from a Gasoline Price Shock in California. Regional Science \& Urban Economics, forthcoming.

Glaeser, Edward L., Matthew E. Kahn, and Jordan Rappaport (2008). Why do the poor live in cities? The role of public transportation. Journal of Urban Economics, 63(1): 1-24.

Goldberg, Pinelopi K (1995). Product differentiation and oligopoly in international markets: The case of the US automobile industry. Econometrica, 63(4): 891-951.

Hausman, Jerry (1976). Individual Discount Rates and the Purchase and Utilization of Energy Using Durables. Rand Journal of Economics, 10(1): 33-54.

Jacobsen, Mark and Arthur van Benthem (2013). Vehicle Scrappage and Gasoline Policy. Working paper.

Johnson, Jaye Pershing (2010). Guide to Federal Buy America Requirements—2009 Supplement. TCRP Legal Research Digest, 31. 
Kahn, Matthew E. (1996). New evidence on trends in vehicle emissions. The RAND Journal of Economics, 27(1): 183-196.

Kirschbaum, Julie B. (2004). Paying for transit operations: challenges and solutions for the Chicago Transit Authority. PhD dissertation, Massachusetts Institute of Technology.

Knittel, C. R. (2012). Automobiles on Steroids: Product Attribute Trade-Offs and Technological Progress in the Automobile Sector. American Economic Review, 101(7): 3368-3399.

Krueger, Ann (1974). "The political economy of the rent-seeking society." American Economic Review, 64(3): 291-303.

Lenway, Stefanie, Randall Morck, and Bernard Yeung (1996). "Rent seeking, protectionism and innovation in the American steel industry." The Economic Journal: 410-421.

Lowinger, Thomas C. (1976). Discrimination in government procurement of foreign goods in the US and Western Europe. Southern Economic Journal, 42(3): 451-460.

McFadden, Daniel (1976). The revealed preferences of a government bureaucracy: Empirical evidence. The Bell Journal of Economics, 7(1): 55-72.

Meyer, John Robert, John F. Kain, and Martin Wohl (1965). The urban transportation problem. Harvard University Press.

Morhing, Herbert (1972). Optimization and Scale Economies in Urban Bus Transportation. American Economic Review, 62(4): 591-604.

Newell, Richard G., Adam B. Jaffe, and Robert N. Stavins (1999). The induced innovation hypothesis and energy-saving technological change. The Quarterly Journal of Economics, 114(3): 941-975.

New Flyer, Annual Information Form, March 2012 http://www.newflyer.com/index/cmsfilesystemaction/investor relations/financial\%20reports/2012 $03 \quad 30$ annual information form.pdf

Parry, Ian WH, and Kenneth A. Small (2005). Does Britain or the United States have the right gasoline tax?. The American Economic Review, 95(4): 1276-1289.

Parry, Ian, and Kenneth Small (2009). Should urban transit subsidies be reduced? American Economic Review, 99(3): 700-724.

Rust, John (1987). Optimal replacement of GMC bus engines: An empirical model of Harold Zurcher. Econometrica: 999-1033.

Savage, Ian (2004). Management objectives and the causes of mass transit deficits. Transportation Research Part A: Policy and Practice 38 (3): 181-199. 
Savage, Ian (2010). The dynamics of fare and frequency choice in urban transit. Transportation Research Part A: Policy and Practice, 44(10): 815-829.

Schofield, Mark L (2004). Evaluating the costs and benefits of increased funding for public transportation in Chicago. PhD dissertation, Massachusetts Institute of Technology.

Small, Kenneth A., and Kurt Van Dender (2007). Fuel efficiency and motor vehicle travel: the declining rebound effect. Energy Journal, 28(1): 25-51.

Train, Kenneth and Clifford Winston (2007). Vehicle Choice Behavior and The Declining Market Share of U.S. Automakers. International Economic Review, 48(4): 1469-1496.

Williamson, Oliver E. (1988). The Logic of Economic Organization. Journal of Law, Economics. \& Organization, 4(1): 65-93. 
Figure 1: Bus and Passenger Car Fleet Fuel Economy (MPG) from 1997 to 2011
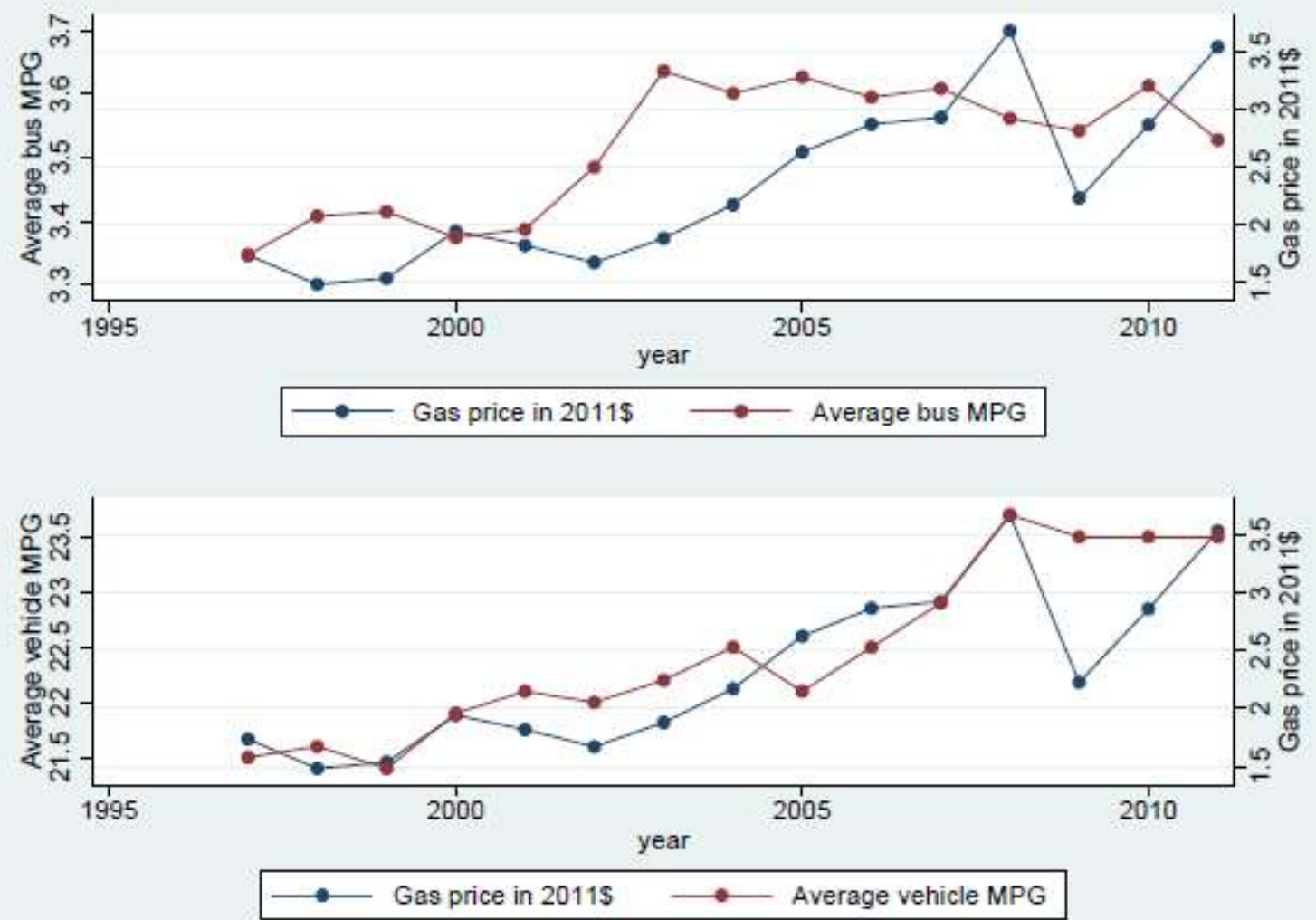

Notes: Bus MPGs (miles per gallon of gasoline) are generated based on total vehicle miles and energy consumption across transit agencies in National Transit Database (NTD) of Federal Transit Administration. We translate all fuels into gasoline equivalent to generate MPG. Passenger vehicle MPGs are from the National Transportation Statistics from the Department of Transportation. 
Figure 2: Bus Scrappage Rate, Lifetime VMT and Fleet by Age
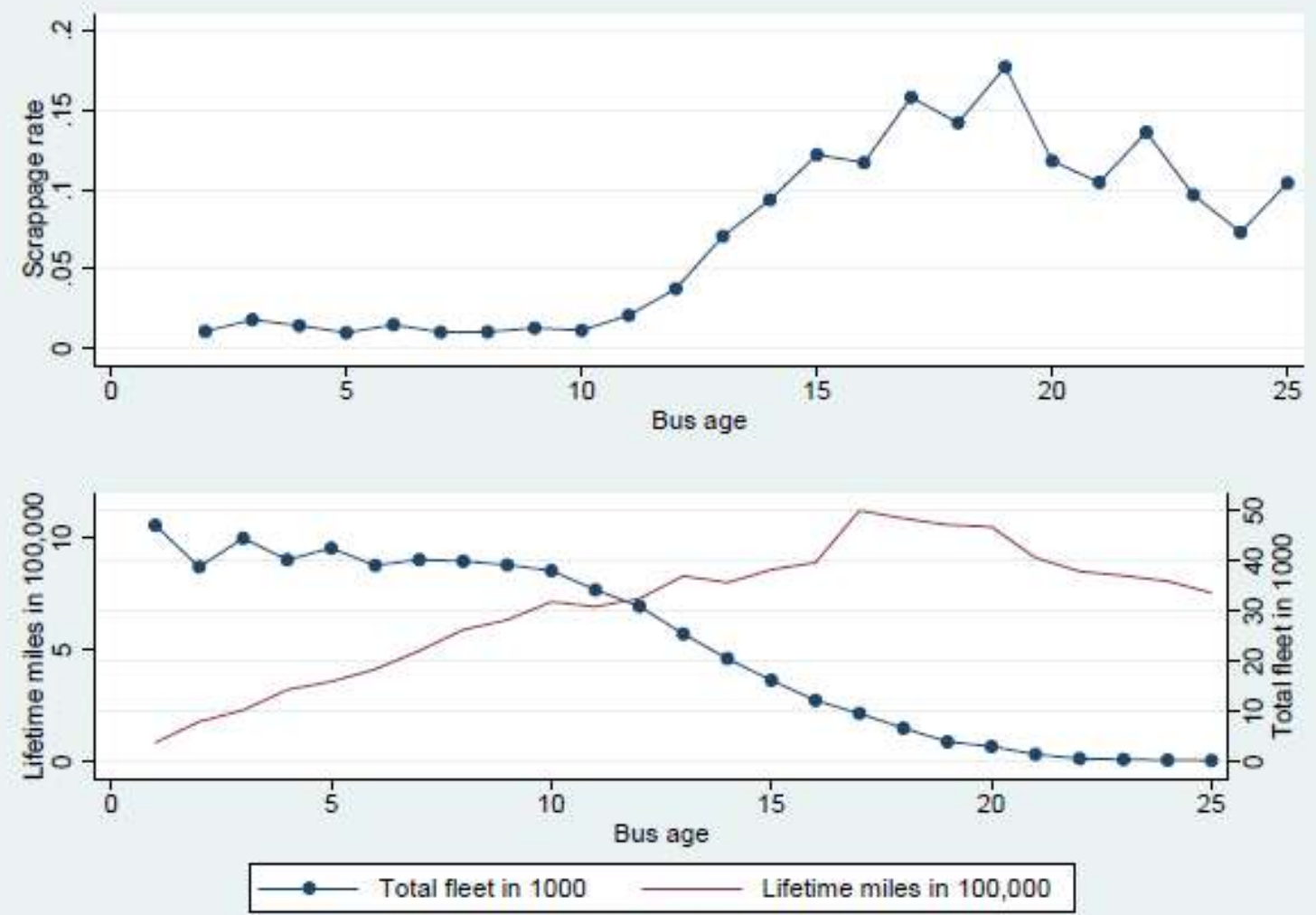

Notes: The plots are based on NTD data from 1997 to 2011. The top panel is the average (year-to-year) scrappage rate by bus age. The bottom panel shows the fleet size and average cumulative miles by age. 
Table 1: Impacts of Fuel Prices on Gallons Per Mile (Total Fuel Consumption/Total VMT)

\begin{tabular}{|c|c|c|c|c|c|c|}
\hline & $\begin{array}{r}(1) \\
\operatorname{Ln}(\mathrm{GPM})\end{array}$ & $\begin{array}{r}(2) \\
\operatorname{Ln}(\mathrm{GPM})\end{array}$ & $\begin{array}{r}(3) \\
\operatorname{Ln}(\mathrm{GPM})\end{array}$ & $\begin{array}{r}(4) \\
\operatorname{Ln}(\mathrm{GPM})\end{array}$ & $\begin{array}{r}(5) \\
\operatorname{Ln}(\mathrm{GPM})\end{array}$ & $\begin{array}{r}(6) \\
\operatorname{Ln}(\mathrm{GPM})\end{array}$ \\
\hline \multirow[t]{2}{*}{ Ln(gasoline price) } & 0.006 & 0.002 & -0.002 & & -0.004 & \\
\hline & $(0.015)$ & $(0.015)$ & $(0.015)$ & & $(0.013)$ & \\
\hline \multirow[t]{2}{*}{$\mathrm{Ln}(\mathrm{CNG}$ price $)$} & 0.005 & 0.007 & 0.008 & & & \\
\hline & $(0.011)$ & $(0.011)$ & $(0.011)$ & & & \\
\hline \multirow[t]{2}{*}{ Ln(gas price:3-year average) } & & & & 0.004 & & 0.027 \\
\hline & & & & $(0.032)$ & & $(0.028)$ \\
\hline \multirow[t]{2}{*}{$\mathrm{Ln}(\mathrm{CNG}$ price:3-year average $)$} & & & & 0.003 & & \\
\hline & & & & $(0.017)$ & & \\
\hline \multirow[t]{2}{*}{ Ln(No. of passengers/mile) } & & $0.044 * *$ & $0.045^{* *}$ & $0.045 * *$ & $0.022 *$ & 0.021 \\
\hline & & $(0.019)$ & $(0.019)$ & $(0.019)$ & $(0.013)$ & $(0.013)$ \\
\hline \multirow[t]{2}{*}{ Average bus age } & & 0.012 & 0.013 & 0.013 & $0.016^{* *}$ & $0.016^{* *}$ \\
\hline & & $(0.008)$ & $(0.008)$ & $(0.008)$ & $(0.007)$ & $(0.007)$ \\
\hline \multirow[t]{2}{*}{ Average bus age squared } & & -0.000 & -0.000 & -0.000 & -0.000 & -0.000 \\
\hline & & $(0.000)$ & $(0.000)$ & $(0.000)$ & $(0.000)$ & $(0.000)$ \\
\hline \multirow[t]{2}{*}{ Time trend } & -0.023 & -0.017 & -0.007 & -0.003 & -0.042 & -0.030 \\
\hline & $(0.015)$ & $(0.015)$ & $(0.032)$ & $(0.034)$ & $(0.031)$ & $(0.032)$ \\
\hline \multirow[t]{2}{*}{ Time trend squared } & -0.006 & -0.007 & -0.006 & -0.008 & 0.009 & 0.002 \\
\hline & $(0.007)$ & $(0.007)$ & $(0.007)$ & $(0.009)$ & $(0.006)$ & $(0.008)$ \\
\hline \multirow[t]{2}{*}{ Constant } & $3.282 * * *$ & $3.108 * * *$ & $3.102 * * *$ & $3.108 * * *$ & $3.142 * * *$ & $3.133 * * *$ \\
\hline & $(0.022)$ & $(0.050)$ & $(0.049)$ & $(0.053)$ & $(0.040)$ & $(0.041)$ \\
\hline Observations & 2748 & 2748 & 2748 & 2748 & 2190 & 2190 \\
\hline
\end{tabular}

Notes: The dependent variable is $\operatorname{Ln}$ (gallons per mile). Gallons per mile is defined as total gasoline consumption/total vehicle miles. The unit of observation is a UZA-year. All regressions include UZA fixed effects. Regressions 3-6 also includes census division specific time trend. The robust standard errors are clustered at the UZA level. Standard errors are in parentheses. $*: p<0.10, * *: p<0.05,{ }^{* * *}: p<0.01$. 
Table 2: New Buses by Make and Type 1997 to 2011

\begin{tabular}{lrr}
\hline Make & No. of new buses & Share (\%) \\
\hline Gillig Corporation & 8,363 & 24.81 \\
New Flyer of America & 7,710 & 22.87 \\
Orion Bus Industries Ltd. & 3,772 & 11.19 \\
NOVA Bus Corporation & 2,740 & 8.13 \\
Motor Coach Industries International & 2,690 & 7.98 \\
North American Bus Industries (NABI) & 2,565 & 7.61 \\
ElDorado National & 1,444 & 4.28 \\
Ford Motor Corporation & 647 & 1.92 \\
Neoplan - USA Corporation & 426 & 1.26 \\
Blue Bird Corporation & 412 & 1.22 \\
Small makes & 2,439 & 7.24 \\
Foreign & 503 & 1.49 \\
\hline Total & 33,711 & 100.00 \\
\hline
\end{tabular}

\begin{tabular}{lrr}
\hline Fuel type & No. of new buses & Share (\%) \\
\hline Diesel & 26,363 & 78.20 \\
CNG & 3,051 & 9.05 \\
Hybrid & 1,736 & 5.15 \\
Other & 2,561 & 7.60 \\
\hline Total & 33,711 & 100.00 \\
\hline
\end{tabular}

Notes: Some of the bus makers merged during the data period but we keep them separate in this table. For example, NABI and Blue Bird merged together in 20062007. In 2013, New Flyer acquired NABI but the NABI brand is kept. 
Table 3: Federal Funding for the Public Transit Capital Stock over the Business Cycle

(1)

$\log ($ feder funding)

year$$
\text { year= } 1994
$$$$
\begin{gathered}
0.001 \\
(0.125)
\end{gathered}
$$$$
-0.066
$$$$
\text { (0.124) }
$$$$
\text { year }=1995
$$$$
0.184
$$$$
\text { (0.134) }
$$$$
\text { year }=1996
$$$$
0.351 * * *
$$$$
\text { (0.128) }
$$$$
\text { year }=1997
$$$$
0.706 * * *
$$$$
\text { year }=1998
$$$$
\text { (0.126) }
$$$$
0.694 * * *
$$$$
\text { (0.132) }
$$$$
\text { year }=1999
$$$$
0.681 * * *
$$$$
\text { (0.135) }
$$$$
\text { year }=2000
$$$$
0.651 * * *
$$$$
\text { (0.124) }
$$$$
\text { year }=2001
$$$$
0.839 * * *
$$$$
\text { (0.127) }
$$$$
\text { year }=2002
$$$$
0.798 * * *
$$$$
\text { (0.132) }
$$$$
\text { year }=2003
$$$$
0.816 * * *
$$$$
\text { (0.122) }
$$$$
\text { year }=2004
$$$$
0.845 * * *
$$$$
\text { (0.126) }
$$$$
\text { year }=2005
$$$$
0.830 * * *
$$$$
\text { (0.131) }
$$$$
\text { year }=2006
$$$$
0.712 * * *
$$$$
\text { (0.125) }
$$$$
\text { year }=2007
$$$$
0.736 * * *
$$$$
\text { (0.126) }
$$$$
\text { year }=2008
$$$$
0.598 * * *
$$$$
\text { (0.129) }
$$$$
\text { year }=2009
$$$$
1.104 * * *
$$$$
\text { (0.131) }
$$$$
\text { year }=2010
$$$$
1.537 * * *
$$$$
\text { (0.124) }
$$$$
\text { year }=2011
$$$$
1.339 * * *
$$$$
\text { (0.128) }
$$

Constant

$$
12.633 * * *
$$$$
\text { (0.098) }
$$

(2)

(3)

Log(federal funding per capita)

share

$-0.001$

$(0.013)$

0.004

(0.013)

$-0.000$

$(0.014)$

0.022

(0.015)

$0.038^{* * *}$

(0.013)

$0.041^{* * *}$

(0.013)

0.021

(0.015)

$0.025 *$

(0.015)

0.027 *

(0.015)

0.018

(0.017)

0.020

(0.016)

0.024

(0.016)

0.023

(0.017)

0.024

(0.017)

$0.030^{*}$

(0.016)

0.010

(0.017)

$0.034 * *$

(0.017)

$0.105 * * *$

(0.016)

$0.093 * * *$

(0.017)

0.690 ***

(0.011)
$-0.001$

$(0.125)$

$-0.061$

(0.124)

0.190

(0.134)

$0.358 * * *$

(0.128)

$0.712 * * *$

(0.126)

$0.699 * * *$

(0.131)

$0.684 * * *$

(0.135)

$0.656 * * *$

(0.124)

$0.654 * * *$

(0.126)

$0.613 * * *$

(0.132)

$0.631 * * *$

(0.122)

$0.661 * * *$

(0.126)

$0.644 * * *$

(0.130)

$0.525 * * *$

(0.125)

$0.550 * * *$

(0.125)

$0.412 * * *$

(0.128)

$0.918^{* * *}$

(0.131)

$1.351 * * *$

(0.124)

$1.023 * * *$

(0.128)

$0.357 * * *$

(0.097)
(4)

$\log$ (total funding per capita)

$-0.010$

(0.112)

$-0.058$

(0.115)

0.179

(0.126)

$0.315^{* * *}$

(0.118)

$0.598 * * *$

(0.118)

$0.582 * * *$

(0.124)

$0.611 * * *$

(0.121)

$0.573 * * *$

(0.116)

$0.584 * * *$

(0.116)

$0.597 * * *$

(0.118)

$0.569 * * *$

(0.111)

$0.589 * * *$

(0.116)

$0.568^{* * *}$

(0.118)

$0.481 * * *$

(0.115)

$0.489 * * *$

(0.118)

$0.401 * * *$

(0.120)

$0.883 * * *$

(0.117)

$1.181 * * *$

(0.115)

$0.873 * * *$

(0.113)

$0.834 * * *$

(0.089)

$\begin{array}{lllll}\text { Observations } & 5206 & 5206 & 5206 & 5206\end{array}$

Notes: All regressions include UZA fixed effects. 1992 is the omitted category. Standard errors in parenthesis are clustered at the UZA level. ${ }^{*} p<0.10,{ }^{* *} p<0.05,{ }^{* * *} p<0.01$. 
Table 4: Summary Statistics of the Bus Inventory Data

\begin{tabular}{lrrrr}
\hline Variable & Mean & Std. Dev. & Min & Max \\
\hline Number of buses & 32.57 & 56.22 & 1.00 & 763.00 \\
Annual scrappage rate & 0.06 & 0.16 & 0.00 & 0.99 \\
Bus age & 8.27 & 5.29 & 1.00 & 25.00 \\
New bus dummy & 0.07 & 0.25 & 0.00 & 1.00 \\
Miles per bus (100,000 miles) & 5.03 & 5.74 & 0.00 & 49.95 \\
Diesel bus & 0.87 & 0.33 & 0.00 & 1.00 \\
CNG bus & 0.10 & 0.30 & 0.00 & 1.00 \\
Hybrid bus & 0.01 & 0.11 & 0.00 & 1.00 \\
Other bus & 0.01 & 0.11 & 0.00 & 1.00 \\
Domestically produced & 0.98 & 0.14 & 0.00 & 1.00 \\
Locally produced & 0.11 & 0.31 & 0.00 & 1.00 \\
Pro-union state & 0.69 & 0.46 & 0.00 & 1.00 \\
Share of the same make & 0.38 & 0.29 & 0.00 & 1.00 \\
Share of the same fuel type & 0.86 & 0.25 & 0.00 & 1.00 \\
Federal funding per capita & 12.73 & 13.41 & 0.00 & 97.02 \\
Total funding per capita & 27.18 & 35.44 & 0.00 & 344.40 \\
PM2.5 nonattainment & 0.16 & 0.35 & 0.00 & 1.00 \\
Ozone nonattainment & 0.31 & 0.45 & 0.00 & 1.00 \\
Population (in 1000000) & 2.90 & 4.49 & 0.05 & 18.35 \\
Gasoline price (in 2011 \$) & 2.42 & 0.71 & 1.27 & 4.05 \\
\hline Notes: The unit of observation
\end{tabular}

Notes: The unit of observation is a vintage-model in a UZA in a year. The number of observations is 19,325 . 
Table 5: The Determinants of Public Transit Bus Scrappage

\begin{tabular}{|c|c|c|c|c|c|}
\hline & $\begin{array}{l}(1) \\
\text { OLS }\end{array}$ & $\begin{array}{c}(2) \\
\text { Tobit }\end{array}$ & $\begin{array}{c}(3) \\
\text { R.E. Tobit }\end{array}$ & $\begin{array}{c}\text { (4) } \\
\text { R.E. Tobit }\end{array}$ & $\begin{array}{c}\text { (5) } \\
\text { R.E. Tobit }\end{array}$ \\
\hline Average bus age & $\begin{array}{c}0.0454 * * * \\
(0.0088)\end{array}$ & $\begin{array}{c}0.1766 * * * \\
(0.0237)\end{array}$ & $\begin{array}{c}0.1769 * * * \\
(0.0239)\end{array}$ & $\begin{array}{c}0.1802 * * * \\
(0.0238)\end{array}$ & $\begin{array}{c}0.1791 * * * \\
(0.0236)\end{array}$ \\
\hline Average age squared & $\begin{array}{c}-0.0001 \\
(0.0003)\end{array}$ & $\begin{array}{c}-0.0027 * * * \\
(0.0006)\end{array}$ & $\begin{array}{c}-0.0026 * * * \\
(0.0006)\end{array}$ & $\begin{array}{c}-0.0026^{* * *} \\
(0.0006)\end{array}$ & $\begin{array}{c}-0.0025^{* * *} \\
(0.0006)\end{array}$ \\
\hline Lifetime mileage & $\begin{array}{c}-0.0118 * * * \\
(0.0037)\end{array}$ & $\begin{array}{c}0.0285 * * * \\
(0.0041)\end{array}$ & $\begin{array}{c}0.0220 * * * \\
(0.0047)\end{array}$ & $\begin{array}{c}0.0234 * * * \\
(0.0047)\end{array}$ & $\begin{array}{c}0.0228 * * * \\
(0.0046)\end{array}$ \\
\hline Lifetime mileage squared & $\begin{array}{l}0.0002 * \\
(0.0001)\end{array}$ & $\begin{array}{c}-0.0006 * * * \\
(0.0002)\end{array}$ & $\begin{array}{c}-0.0004 * * \\
(0.0002)\end{array}$ & $\begin{array}{c}-0.0005 * * * \\
(0.0002)\end{array}$ & $\begin{array}{c}-0.0005^{* * *} \\
(0.0002)\end{array}$ \\
\hline PM or Ozone nonattainment*old bus & $\begin{array}{c}0.0176 \\
(0.0110)\end{array}$ & $\begin{array}{c}0.0874 * * * \\
(0.0254)\end{array}$ & $\begin{array}{c}0.0639 * * \\
(0.0274)\end{array}$ & $\begin{array}{c}0.0824 * * * \\
(0.0285)\end{array}$ & $\begin{array}{c}0.0744 * * * \\
(0.0281)\end{array}$ \\
\hline Population growth*old bus & $\begin{array}{c}0.0712 \\
(0.0522)\end{array}$ & $\begin{array}{c}0.0239 \\
(0.1550)\end{array}$ & $\begin{array}{l}-0.1483 \\
(0.1595)\end{array}$ & $\begin{array}{c}0.1856 \\
(0.1775)\end{array}$ & $\begin{array}{c}0.0819 \\
(0.1780)\end{array}$ \\
\hline Area growth*old bus & $\begin{array}{c}-0.0749^{*} \\
(0.0428)\end{array}$ & $\begin{array}{c}-0.0453 \\
(0.1275)\end{array}$ & $\begin{array}{c}0.0296 \\
(0.1346)\end{array}$ & $\begin{array}{c}-0.1558 \\
(0.1481)\end{array}$ & $\begin{array}{c}0.0215 \\
(0.1483)\end{array}$ \\
\hline $\operatorname{Ln}($ gas price $) *$ old diesel bus & $\begin{array}{c}0.0050 \\
(0.0170)\end{array}$ & $\begin{array}{c}-0.0269 \\
(0.0570)\end{array}$ & $\begin{array}{c}-0.0222 \\
(0.0580)\end{array}$ & $\begin{array}{c}-0.0094 \\
(0.0584)\end{array}$ & $\begin{array}{c}-0.0039 \\
(0.0578)\end{array}$ \\
\hline Ln(gas price)*old CNG bus & $\begin{array}{l}-0.0095 \\
(0.0084)\end{array}$ & $\begin{array}{c}-0.0220 \\
(0.0321)\end{array}$ & $\begin{array}{c}-0.0182 \\
(0.0333)\end{array}$ & $\begin{array}{c}-0.0204 \\
(0.0332)\end{array}$ & $\begin{array}{l}-0.0228 \\
(0.0327)\end{array}$ \\
\hline Ln(GSP per capita)*old bus & $\begin{array}{c}-0.0038 * * \\
(0.0016)\end{array}$ & $\begin{array}{c}-0.0029 \\
(0.0056)\end{array}$ & $\begin{array}{c}-0.0026 \\
(0.0057)\end{array}$ & $\begin{array}{c}-0.0052 \\
(0.0057)\end{array}$ & $\begin{array}{c}-0.0228 * * * \\
(0.0060)\end{array}$ \\
\hline Ln(federal funding/pop)*old bus & & & & & $\begin{array}{c}0.0772 * * * \\
(0.0087)\end{array}$ \\
\hline Constant & $\begin{array}{c}-0.0118^{* * *} \\
(0.0037)\end{array}$ & $\begin{array}{c}0.0285^{* * *} \\
(0.0041) \\
\end{array}$ & $\begin{array}{c}0.0220 * * * \\
(0.0047) \\
\end{array}$ & $\begin{array}{c}0.0234 * * * \\
(0.0047) \\
\end{array}$ & $\begin{array}{c}0.0228 * * * \\
(0.0046) \\
\end{array}$ \\
\hline Year fixed effects & Yes & Yes & Yes & Yes & Yes \\
\hline Manufacturer fixed effects & No & Yes & Yes & Yes & Yes \\
\hline State fixed effects & No & Yes & No & Yes & Yes \\
\hline UZA-vintage-model fixed effects & Yes & No & No & No & No \\
\hline S.D. of random effects & & & $\begin{array}{c}0.1956^{* * *} \\
(0.0109)\end{array}$ & $\begin{array}{c}0.1702 * * * \\
(0.0111)\end{array}$ & $\begin{array}{c}0.1596 * * * \\
(0.0112)\end{array}$ \\
\hline S.D. of error term & & $\begin{array}{c}0.4260 * * * \\
(0.0075)\end{array}$ & $\begin{array}{c}0.3975^{* * * *} \\
(0.0073)\end{array}$ & $\begin{array}{c}0.3976^{* * * *} \\
(0.0073)\end{array}$ & $\begin{array}{c}0.3957 * * * \\
(0.0073)\end{array}$ \\
\hline
\end{tabular}

Notes: The dependent variable is the scrappage rate by vintage-model by UZA and year. The number of

observations is 10,314. All the regressions include dummies variables for three vintages (pre-1980 buses, 1980 to 1990, 1990 to 2000) and CNG bus dummy. PM or Ozone nonattainment captures PM or Ozone attainment status of the counties in the UZA. Columns (3) and (5) use random effects to control for UZA-make un-observables. Standard errors are in parentheses. ${ }^{*} p<0.10,{ }^{* *} p<0.05,{ }^{* * *} p<0.01$. 
Table 6: The Determinants of New Bus Purchases

\begin{tabular}{lccccc}
\hline & $(1)$ & $(2)$ & $(3)$ & $(4)$ & $(5)$ \\
& OLS & Tobit & R.E. Tobit & R.E. Tobit & R.E. Tobit \\
\hline Local dummy & -0.016 & $0.264^{* *}$ & $0.503^{* * *}$ & $0.457^{* *}$ & $0.449^{* *}$ \\
& $(0.024)$ & $(0.114)$ & $(0.182)$ & $(0.194)$ & $(0.193)$ \\
Pro-union state*Domestic bus & 0.017 & 0.275 & 0.094 & 0.426 & 0.400 \\
& $(0.011)$ & $(0.192)$ & $(0.079)$ & $(0.277)$ & $(0.275)$ \\
\% of old buses from the same make & $0.515^{* * *}$ & $3.378^{* * *}$ & $1.812^{* * *}$ & $1.844^{* * *}$ & $1.866^{* * *}$ \\
& $(0.025)$ & $(0.138)$ & $(0.163)$ & $(0.164)$ & $(0.165)$ \\
Ln(federal funding/pop)*Domestic bus & & & & & $0.008^{* * *}$ \\
& & & & & $(0.003)$ \\
Constant & $0.066^{* * *}$ & $-2.164^{* * *}$ & $-1.676^{* * *}$ & $-2.342^{* * *}$ & $-2.360^{* * *}$ \\
& $(0.012)$ & $(0.299)$ & $(0.144)$ & $(0.427)$ & $(0.425)$ \\
\hline Year fixed effects & Yes & Yes & Yes & Yes & Yes \\
Manufacturer fixed effects & Yes & Yes & Yes & Yes & Yes \\
State fixed effects & No & Yes & No & Yes & Yes \\
UZA fixed effects & Yes & No & No & No & No \\
\hline S.D. of random effects & & & $1.114^{* * *}$ & $1.105^{* * *}$ & $1.096^{* * *}$ \\
S.D. of error term & & & $(0.053)$ & $(0.053)$ & $(0.053)$ \\
& & $1.757^{* * *}$ & $1.479^{* * *}$ & $1.481^{* * *}$ & $1.483^{* * *}$ \\
& & $(0.046)$ & $(0.040)$ & $(0.040)$ & $(0.040)$ \\
\hline
\end{tabular}

Notes: The dependent variable is the share of new buses by make among all new buses purchased by a UZA in a year. The number of observations is 15,230 . Columns (3) and (5) use random effects to control for UZA-make unobservables. Standard errors are in parentheses. ${ }^{*} p<0.10,{ }^{* *} p<0.05,{ }^{* * *} p<0.01$. 
Table 7: The Determinants of New Bus Fuel Type

\begin{tabular}{|c|c|c|c|c|c|}
\hline & $\begin{array}{c}(1) \\
\text { OLS }\end{array}$ & $\begin{array}{c}\text { (2) } \\
\text { Tobit }\end{array}$ & $\begin{array}{c}\text { (3) } \\
\text { R.E. Tobit }\end{array}$ & $\begin{array}{c}\text { (4) } \\
\text { R.E. Tobit }\end{array}$ & $\begin{array}{c}\text { (5) } \\
\text { R.E. Tobit }\end{array}$ \\
\hline PM or Ozone nonat. $*$ diesel bus & $\begin{array}{l}-0.043 \\
(0.030)\end{array}$ & $\begin{array}{c}-0.355 * * * \\
(0.136)\end{array}$ & $\begin{array}{c}-0.535^{* * *} \\
(0.172)\end{array}$ & $\begin{array}{c}-0.576^{* * *} \\
(0.183)\end{array}$ & $\begin{array}{c}-0.551 * * * \\
(0.181)\end{array}$ \\
\hline PM or Ozone nonat. ${ }^{*} \mathrm{CNG}$ bus & $\begin{array}{c}0.033 \\
(0.028)\end{array}$ & $\begin{array}{c}0.305 * * \\
(0.152)\end{array}$ & $\begin{array}{c}0.620 * * * \\
(0.204)\end{array}$ & $\begin{array}{c}0.579 * * * \\
(0.215)\end{array}$ & $\begin{array}{c}0.567 * * * \\
(0.212)\end{array}$ \\
\hline PM or Ozone nonat.*hybrid bus & $\begin{array}{c}0.039 \\
(0.040)\end{array}$ & $\begin{array}{c}0.206 \\
(0.214)\end{array}$ & $\begin{array}{c}0.243 \\
(0.262)\end{array}$ & $\begin{array}{c}0.178 \\
(0.278)\end{array}$ & $\begin{array}{c}0.114 \\
(0.274)\end{array}$ \\
\hline $\operatorname{Ln}($ gas price $) *$ diesel bus & $\begin{array}{l}-0.009 \\
(0.184)\end{array}$ & $\begin{array}{l}-0.587 \\
(1.321)\end{array}$ & $\begin{array}{l}-0.505 \\
(0.784)\end{array}$ & $\begin{array}{l}-0.520 \\
(1.228)\end{array}$ & $\begin{array}{l}-0.566 \\
(1.232)\end{array}$ \\
\hline $\mathrm{Ln}($ gas price $) * \mathrm{CNG}$ bus & $\begin{array}{c}0.082 \\
(0.183)\end{array}$ & $\begin{array}{c}0.536 \\
(1.335)\end{array}$ & $\begin{array}{l}-0.244 \\
(0.815)\end{array}$ & $\begin{array}{l}-0.254 \\
(1.259)\end{array}$ & $\begin{array}{l}-0.169 \\
(1.263)\end{array}$ \\
\hline Ln(gas price)*hybrid bus & $\begin{array}{c}0.053 \\
(0.225)\end{array}$ & $\begin{array}{c}0.368 \\
(1.666)\end{array}$ & $\begin{array}{c}0.829 \\
(1.205)\end{array}$ & $\begin{array}{c}0.800 \\
(1.588)\end{array}$ & $\begin{array}{c}0.891 \\
(1.597)\end{array}$ \\
\hline $\operatorname{Ln}(\mathrm{CNG} \text { price })^{*}$ diesel bus & $\begin{array}{c}0.031 \\
(0.023)\end{array}$ & $\begin{array}{l}0.285^{*} \\
(0.170)\end{array}$ & $\begin{array}{c}0.212 \\
(0.162)\end{array}$ & $\begin{array}{c}0.239 \\
(0.167)\end{array}$ & $\begin{array}{c}0.264 \\
(0.169)\end{array}$ \\
\hline $\mathrm{Ln}(\mathrm{CNG}$ price $) * \mathrm{CNG}$ bus & $\begin{array}{l}-0.021 \\
(0.019)\end{array}$ & $\begin{array}{c}-0.437 * * \\
(0.201)\end{array}$ & $\begin{array}{l}-0.257 \\
(0.205)\end{array}$ & $\begin{array}{l}-0.235 \\
(0.211)\end{array}$ & $\begin{array}{l}-0.267 \\
(0.213)\end{array}$ \\
\hline Ln(CNG price)*hybrid bus & $\begin{array}{l}-0.009 \\
(0.036)\end{array}$ & $\begin{array}{c}0.242 \\
(0.264)\end{array}$ & $\begin{array}{c}0.252 \\
(0.276)\end{array}$ & $\begin{array}{c}0.335 \\
(0.297)\end{array}$ & $\begin{array}{c}0.256 \\
(0.299)\end{array}$ \\
\hline$\%$ of buses of the same fuel type & $\begin{array}{c}0.899 * * * \\
(0.037)\end{array}$ & $\begin{array}{c}4.943 * * * \\
(0.278)\end{array}$ & $\begin{array}{c}3.467 * * * \\
(0.353)\end{array}$ & $\begin{array}{c}3.482 * * * \\
(0.354)\end{array}$ & $\begin{array}{c}3.570 * * * \\
(0.351)\end{array}$ \\
\hline$\%$ democratic votes $*$ hybrid bus & $\begin{array}{c}0.194 \\
(0.261)\end{array}$ & $\begin{array}{c}1.629 \\
(1.833)\end{array}$ & $\begin{array}{c}1.591 \\
(2.109)\end{array}$ & $\begin{array}{c}1.823 \\
(2.377)\end{array}$ & $\begin{array}{c}1.180 \\
(2.335)\end{array}$ \\
\hline $\operatorname{Ln}(\mathrm{GSP}) *$ hybrid bus & $\begin{array}{c}0.066 \\
(0.118)\end{array}$ & $\begin{array}{c}0.393 \\
(0.938)\end{array}$ & $\begin{array}{c}0.265 \\
(1.076)\end{array}$ & $\begin{array}{c}0.092 \\
(1.238)\end{array}$ & $\begin{array}{l}-0.262 \\
(1.226)\end{array}$ \\
\hline $\operatorname{Ln}($ federal funding/pop)*hybrid & & & & & $\begin{array}{c}0.406 * * * \\
(0.126)\end{array}$ \\
\hline Constant & $\begin{array}{l}-0.058 \\
(0.097)\end{array}$ & $\begin{array}{c}-2.835 * * * \\
(0.693)\end{array}$ & $\begin{array}{c}-1.133 * * \\
(0.557)\end{array}$ & $\begin{array}{l}-1.261 \\
(0.778)\end{array}$ & $\begin{array}{l}-1.380 * \\
(0.771)\end{array}$ \\
\hline Year fixed effects & Yes & Yes & Yes & Yes & Yes \\
\hline Fuel type fixed effects & Yes & Yes & Yes & Yes & Yes \\
\hline State fixed effects & No & Yes & No & Yes & Yes \\
\hline UZA fixed effects & Yes & No & No & No & No \\
\hline S.D. of random effects & & & $\begin{array}{c}1.005 * * * \\
(0.096)\end{array}$ & $\begin{array}{c}1.001 * * * \\
(0.095)\end{array}$ & $\begin{array}{c}0.951 * * * \\
(0.093)\end{array}$ \\
\hline S.D. of error term & & $\begin{array}{c}1.489 * * * \\
(0.071)\end{array}$ & $\begin{array}{c}1.244 * * * \\
(0.062)\end{array}$ & $\begin{array}{c}1.244 * * * \\
(0.062)\end{array}$ & $\begin{array}{c}1.250 * * * \\
(0.062)\end{array}$ \\
\hline
\end{tabular}

Note: The dependent variable is the share of new buses by fuel type (diesel, CNG or hybrid) among new buses purchased in a UZA in a year. The number of observations is 3,479. Columns (3) and (5) use random effects to control for UZA-fuel type un-observables. Standard errors are in parentheses. ${ }^{*} p<0.10,{ }^{* *} p<0.05,{ }^{* * *} p<0.01$. 


\section{Web Appendix}

\section{Appendix Table 1: Impacts of Fuel Prices on GPM (Total Fuel Consumption/Total VMT)}

\begin{tabular}{lcccc}
\hline & $\begin{array}{c}(1) \\
\text { Ln(GPM) } \\
\text { All data }\end{array}$ & $\begin{array}{c}(2) \\
\text { Ln(GPM) } \\
\text { Pop }>300 \mathrm{k}\end{array}$ & $\begin{array}{c}(3) \\
\text { Ln(GPM) } \\
\text { Growing } \\
\text { Cities }\end{array}$ & $\begin{array}{c}(4) \\
\text { Ln(GPM) } \\
\text { Recession }\end{array}$ \\
\hline Ln(gasoline price) & -0.002 & 0.014 & 0.003 & -0.019 \\
& $(0.015)$ & $(0.026)$ & $(0.018)$ & $(0.022)$ \\
Ln(CNG price) & 0.008 & -0.010 & 0.007 & 0.030 \\
& $(0.011)$ & $(0.015)$ & $(0.013)$ & $(0.023)$ \\
Ln(No. of passenger/mile) & $0.045^{* *}$ & 0.058 & $0.077^{* * *}$ & 0.031 \\
Average bus age & $(0.019)$ & $(0.038)$ & $(0.028)$ & $(0.036)$ \\
& 0.013 & 0.015 & 0.006 & 0.009 \\
Average bus age squared & $(0.008)$ & $(0.016)$ & $(0.011)$ & $(0.011)$ \\
Time trend & -0.000 & -0.001 & -0.000 & -0.000 \\
Time trend squared & $(0.000)$ & $(0.001)$ & $(0.001)$ & $(0.001)$ \\
Constant & -0.007 & 0.001 & 0.000 & -0.247 \\
& $(0.032)$ & $(0.034)$ & $(0.046)$ & $(0.242)$ \\
Observations & -0.006 & -0.009 & -0.009 & 0.047 \\
& $(0.007)$ & $(0.012)$ & $(0.008)$ & $(0.053)$ \\
& $3.102^{* * *}$ & $3.176^{* * *}$ & $3.089 * * *$ & $3.331^{* * *}$ \\
& $(0.049)$ & $(0.106)$ & $(0.067)$ & $(0.263)$ \\
\hline
\end{tabular}

Note: The dependent variable is Ln(gallons per mile). The unit of observation is UZA-year. All regressions include UZA fixed effects and census division specific time trend. Column (1) is the same as column (3) in Table 3.

Column (2) focuses on UZAs with population over 300,000. Column (3) focuses on UZAs with a 10-year population growth rate over $5 \%$, accounting for three quarters of all UZAs in the data. Column (4) only includes observations in 2001, 2002, 2008, 2009, and 2010 (recession years). The robust standard errors are clustered at the UZA level *: $p<0.10, * *: p<0.05, * * *: p<0.01$. 


\section{Web Appendix 2: The Supply Response of Buses to Fuel Prices}

We examine how the supply side in the bus market responds to fuel price changes by changing the fuel economy of new buses sold. We contrast this with the supply side of the passenger car market following the strategy of Knittel (2012). While he examines the tradeoff of fuel economy and other characteristics in the car market through the production frontier, our focus here is on how fuel prices affect the supply side. For the passenger car market, we supplement Knittel's data with gasoline prices and examine how gasoline prices affect the tradeoff.

Let $j$ index a vehicle model and $v$ index vintage (year-built), our econometric analysis starts with the specification of how fuel price prices affect fuel economy of vintage-model:

$$
G P M_{j v}=\alpha_{j}+\beta F P_{v}+Z_{j v} \delta+\gamma v+\varepsilon_{j v}
$$

where $G P M_{j v}$ is gallons per mile of model $j$ and vintage $v . \alpha_{j}$ captures the mean fuel economy of model $j$ over time and controls for average characteristics of the buses. $F P_{v}$ is fuel price in year $v$. $Z_{j v}$ is a vector of vehicle characteristics such as weight and horsepower. $\gamma v$ controls for time trend of technology progress.

For passenger cars, the results from four specifications are presented in Appendix Table 2 below. The first two use gasoline prices averaged over the past three years while the last two use the past five years. The parameter estimates on gasoline price variables are quite stable across four specifications. The first specification shows that a $10 \%$ increase in gasoline prices would lead to about a 0.0035 decrease in GPM, implying that MPG would goes up from 22 to 23.8.

For buses, since we do not have information on bus characteristics, we cannot directly examine how fuel price changes affect the fuel economy of the buses produced using the above framework. Instead, we make the inference based on the UZA-year fuel consumption data and information on bus fleet, in particular, mileage by vintage-make. Fuel consumption of UZA $c$ at year $t$ is given by $Y_{c t} \equiv \sum_{j} \sum_{v} m_{c t j v} G P M_{j v}$, where $m_{c t j v}$ is the total mileage of buses of model $j$ and vintage $v$ in UZA $c$ at year $t$. Replacing $G P M_{j v}$ with equation (1), we take the following equation to data:

$$
\begin{gathered}
Y_{c t}=\sum_{j} \sum_{v} m_{c t j v}\left(\alpha_{j}+\beta F P_{v}+Z_{j v} \delta+\gamma v+\varepsilon_{j v}\right) \\
=\sum_{j} \alpha_{j} \sum_{v} m_{c t j v}+\beta \sum_{j} \sum_{v} m_{c t j v} F P_{v}+\sum_{j} \sum_{v} m_{c t j v} Z_{j v} \delta+\gamma \sum_{j} \sum_{v} m_{c t j v} v+e_{c t}
\end{gathered}
$$




$$
=\sum_{j} \alpha_{j} M_{c t}+\beta M P_{c t}+\gamma M V_{c t}+\zeta_{c t} .
$$

The variables $M_{c t}$ (total mileage), $M P_{c t}$ (summation of mileage* gasoline price), $M V_{c t}$ (summation of mileage*time trend) are the regressors and can be constructed based on our data. Similar to the regressions on private cars, we construct lagged 3-year average and 5-year average gasoline prices and use them to interact with vintage-make specific mileage data.

$\zeta_{c t}$, the new composite error term, include the interactions of mileage with other bus characteristics, which we do not observe for buses. Parameter $\beta$ captures the effect of gasoline prices of bus fuel economy. If a higher gas price leads to firms to produce more fuel-efficient buses, $\beta$ should be negative. In addition, to the extent that unobserved bus characteristics such as vehicle weight and horsepower are positively correlated with GPM and negatively correlated with gasoline prices, the estimate of $\beta$ from the above regression would have a downward bias.

This analysis examines the supply side response based on the fuel economy of all buses (which is associated with observed total energy consumption) and fuel prices at the production of these buses. Appendix Table 3 shows that the coefficient estimates on gasoline prices for bus fuel economy are neither robust in sign nor statistically significant across specifications. This is in contrast with the finding for the passenger vehicle market. 
Appendix Table 2: Fuel Economy of Cars as a Function of Gas Prices 1980-2006

\begin{tabular}{lcccc}
\hline & $(1)$ & $(2)$ & $(3)$ & $(4)$ \\
& GPM & GPM & GPM & GPM \\
\hline Ln(gas price:3-year average) & $-0.0035^{* * *}$ & $-0.0048^{* * *}$ & & \\
& $(0.0010)$ & $(0.0008)$ & & \\
Ln(gas price:5-year average) & & & $-0.0030^{* *}$ & $-0.0039^{* * *}$ \\
& & & $(0.0012)$ & $(0.0008)$ \\
Time trend (ln(year-1979)) & $-0.0012^{* * *}$ & -0.0005 & $-0.0007 * * *$ & -0.0002 \\
& $(0.0003)$ & $(0.0004)$ & $(0.0002)$ & $(0.0003)$ \\
Time trend squared & & $-0.0029 * * *$ & & -0.0015 \\
& & $(0.0003)$ & & $(0.0009)$ \\
Constant & -0.0153 & $-0.3301 * * *$ & -0.0027 & $-0.1626^{*}$ \\
& $(0.0169)$ & $(0.0885)$ & $(0.0132)$ & $(0.0903)$ \\
\hline Observations & 27046 & 27046 & 27046 & 27046 \\
\hline
\end{tabular}

Notes: The dependent variable is gallons per mile of each vintage-model from 1980 to 2006. All data except gasoline prices are from Knittel (2012). All regressions are from OLS and include manufacturer fixed effects. The control variables (not shown in the regressions) also include $\ln$ (curb weight), $\ln$ (horsepower), $\ln$ (torque), manual dummy, diesel dummy, turbocharge dummy and supercharged dummy. The standard errors are clustered at the manufacturer level. ${ }^{*} p<0.10,{ }^{* *} p<0.05,{ }^{* * *} p<0.01$.

Appendix Table 3: Fuel Economy of Buses as a Function of Gas Prices 1997-2011

\begin{tabular}{lcccc}
\hline & $(1)$ & $(2)$ & $(3)$ & $(4)$ \\
& GPM & GPM & GPM & GPM \\
\hline Ln(gas price:3-year average) & 0.0223 & 0.0060 & & \\
& $(0.0418)$ & $(0.0438)$ & & \\
Ln(gas price:5-year average) & & & 0.0002 & -0.0341 \\
& & & $(0.0551)$ & $(0.0640)$ \\
Time trend ( ln(year-1979) ) & $-0.0393 * *$ & -0.0691 & -0.0321 & -0.0858 \\
& $(0.0177)$ & $(0.0751)$ & $(0.0203)$ & $(0.0734)$ \\
Time trend squared & & 0.0082 & & 0.0151 \\
& & $(0.0188)$ & & $(0.0190)$ \\
Constant & $1.0542^{* * *}$ & $1.0611^{* * *}$ & $1.0622^{* * *}$ & $1.0666^{* * *}$ \\
& $(0.1643)$ & $(0.1667)$ & $(0.1647)$ & $(0.1624)$ \\
\hline Observations & 3063 & 3063 & 3063 & 3063 \\
\hline
\end{tabular}

Notes: The unit of observation is UZA-year. The coefficient estimates corresponds to the coefficients in equation (1) and are estimated based on equation (2). All regressions include manufacturer fixe effects, UZA fixed effects, year fixed effects, and census division specific time trend. The robust standard errors in parenthesis are clustered at the city level. *: $p<0.10, * *: p<0.05, * * *: p<0.01$. 


\section{Appendix 3: Proof of Proposition 2}

Proof: first, suppose there is no subsidy at time t. Let $g^{* *} \cong 1$ and $a \cong \zeta$ sufficiently small. At time $t$,

$$
S_{t}\left(\frac{T-i\left(1-g_{t}\right)-a-\mu\left(M_{t}\right)}{w+P_{t} \alpha\left(V^{* *}\right)}, V^{* *}\right) \cong S_{t}\left(\frac{T-i-\zeta-\mu\left(M_{t}\right)}{w+P_{t} \alpha\left(V^{* *}\right)}, V^{* *}\right)
$$

and with a subsidy at $t+1$,

$$
\begin{gathered}
S_{t+1}\left(\frac{T-i\left(1-g_{t+1}\right)-a-\mu\left(M_{t}\right)}{w+P_{t+1} \alpha\left(V^{* *}\right)}, V^{* *}\right) \cong S_{t}\left(\frac{T-\zeta-\mu\left(M_{t}\right)}{w+P_{t+1} \alpha\left(V^{* *}\right)}, V^{* *}\right) . \\
\Phi^{*}=S_{t}\left(\frac{T-\mu\left(M_{t}\right)}{w+P_{t} \alpha\left(V^{*}\right)}, V^{*}\right)+\beta \rho \Phi_{t+1}\left(. \mid V_{t}=V^{*}, g^{* *}\right)+\beta(1-\rho) \Phi_{t+1}\left(. \mid V_{t}=V^{*}, 0\right) \\
=S_{t}\left(\frac{T-\mu\left(M_{t}\right)}{w+P_{t} \alpha\left(V^{*}\right)}, V^{*}\right)+\beta \rho S_{t}\left(\frac{T-\zeta-\mu\left(M_{t}\right)}{w+P_{t+1} \alpha\left(V^{* *}\right)}, V^{* *}\right) \\
+\beta^{2} \rho S_{t}\left(\frac{T-\mu\left(M_{t}\right)}{w+P_{t+1} \alpha\left(V^{* *}\right)}, V^{* *}\right) /(1-\beta), \\
\Phi^{* *}=\beta S_{t}+S_{t}\left(\frac{T-i-\mu\left(M_{t}\right)}{w+P_{t+1} \alpha\left(V^{* *}\right)}, V^{* *}\right) /(1-\beta)+S_{t}\left(\frac{T-i-\zeta-\mu\left(M_{t}\right)}{w+P_{t+1} \alpha\left(V^{* *}\right)}, V^{* *}\right) .
\end{gathered}
$$

Subtracting

$$
\begin{aligned}
\Phi^{*}-\Phi^{* *}= & S_{t}\left(\frac{T-\mu\left(M_{t}\right)}{w+P_{t} \alpha\left(V^{*}\right)}, V^{*}\right)+\left[\beta \rho S_{t}\left(\frac{T-\zeta-\mu\left(M_{t}\right)}{w+P_{t+1} \alpha\left(V^{* *}\right)}, V^{* *}\right)-S_{t}\left(\frac{T-i-\zeta-\mu\left(M_{t}\right)}{w+P_{t+1} \alpha\left(V^{* *}\right)}, V^{* *}\right)\right] \\
& +\frac{\beta}{1-\beta}\left[\beta \rho S_{t}\left(\frac{T-\mu\left(M_{t}\right)}{w+P_{t+1} \alpha\left(V^{* *}\right)}, V^{* *}\right)-S_{t+1}\left(\frac{T-i-\mu\left(M_{t}\right)}{w+P_{t+1} \alpha\left(V^{* *}\right)}, V^{* *}\right)\right] .
\end{aligned}
$$

The first term is positive, and for $\beta \rho$ close to 1 , each of the terms in brackets is positive. Therefore $V_{t}=V^{*}$. 
Appendix Table 4: Multinomial Logit Regressions of Bus Purchase Decisions

\begin{tabular}{|c|c|c|c|c|c|c|c|c|}
\hline \multirow[b]{2}{*}{ Variables } & \multicolumn{2}{|c|}{ MNL } & \multicolumn{2}{|c|}{ R.E. MNL } & \multicolumn{2}{|c|}{ MNL } & \multicolumn{2}{|c|}{ R.E. MNL } \\
\hline & Coef. & S.E. & Coef. & S.E. & Coef. & S.E. & Coef. & S.E. \\
\hline $\operatorname{Ln}($ pop) & -35.521 & 14.924 & -41.801 & 17.692 & -26.142 & 15.915 & -31.799 & 18.991 \\
\hline $\operatorname{Ln}($ area $)$ & 0.645 & 0.158 & 0.913 & 0.303 & 0.334 & 0.166 & 0.438 & 0.297 \\
\hline Ln(Gross state product per capita) & 0.034 & 0.160 & -0.003 & 0.312 & 0.297 & 0.169 & 0.342 & 0.293 \\
\hline Average bus age & -0.367 & 0.336 & -0.062 & 0.650 & -0.606 & 0.347 & -0.162 & 0.660 \\
\hline Ln(mileage per bus) & 0.036 & 0.015 & 0.064 & 0.024 & 0.020 & 0.016 & 0.050 & 0.024 \\
\hline Local bus dummy & -0.060 & 0.040 & 0.040 & 0.058 & 0.031 & 0.040 & 0.103 & 0.050 \\
\hline Pro-union state*Domestic bus & 0.898 & 0.198 & 1.120 & 0.237 & 0.889 & 0.200 & 1.096 & 0.243 \\
\hline$\%$ of old buses from the same make & 1.443 & 0.809 & 1.967 & 1.642 & 1.209 & 0.842 & 1.327 & 1.686 \\
\hline PM or Ozone nonat*diesel bus & 2.306 & 0.112 & 2.307 & 0.143 & 2.341 & 0.113 & 2.341 & 0.147 \\
\hline PM or Ozone nona*cng bus & -0.036 & 0.099 & -0.133 & 0.172 & -0.102 & 0.103 & -0.145 & 0.176 \\
\hline PM or Ozone nona*hybrid bus & 0.415 & 0.200 & 0.520 & 0.297 & 0.383 & 0.202 & 0.489 & 0.299 \\
\hline $\operatorname{Ln}($ gas price $) *$ diesel bus & 0.230 & 0.330 & 0.163 & 0.385 & 0.199 & 0.340 & 0.191 & 0.417 \\
\hline $\operatorname{Ln}($ gas price $) * \operatorname{cng}$ bus & 0.145 & 0.833 & -0.621 & 1.324 & -0.453 & 0.873 & -1.112 & 1.371 \\
\hline $\operatorname{Ln}($ gas price)*hybrid bus & 0.792 & 0.999 & -0.248 & 1.679 & 0.164 & 1.031 & -0.741 & 1.735 \\
\hline $\operatorname{Ln}(\text { cng price })^{*}$ diesel bus & 0.276 & 1.181 & -0.531 & 1.623 & -0.180 & 1.216 & -0.875 & 1.667 \\
\hline $\operatorname{Ln}(\text { cng price })^{*}$ cng bus & -0.078 & 0.116 & -0.237 & 0.141 & -0.100 & 0.121 & -0.251 & 0.148 \\
\hline $\operatorname{Ln}($ cng price $) *$ hybrid bus & -0.485 & 0.309 & -0.558 & 0.459 & -0.497 & 0.312 & -0.575 & 0.479 \\
\hline$\%$ of old buses from the same fuel type & -0.554 & 0.418 & -0.686 & 0.530 & -0.638 & 0.441 & -0.777 & 0.561 \\
\hline$\%$ democratic votes $*$ hybrid bus & 2.811 & 0.185 & 2.984 & 0.282 & 2.893 & 0.188 & 3.054 & 0.276 \\
\hline Ln(GSP)*hybrid bus & 0.359 & 2.623 & 0.199 & 2.705 & 0.789 & 2.610 & 0.713 & 2.682 \\
\hline Capital funding per capita & 1.486 & 1.493 & 1.384 & 1.649 & 0.918 & 1.568 & 0.795 & 1.720 \\
\hline Federal funding *domestic dummy & 1.886 & 1.047 & 1.741 & 1.440 & 1.862 & 1.063 & 1.730 & 1.494 \\
\hline Capital funding *hybrid dummy & 3.110 & 1.752 & 3.017 & 2.394 & 3.152 & 1.773 & 3.040 & 2.453 \\
\hline R.E. at UZA-make level & No & & 0.780 & 0.070 & No & & 0.786 & 0.072 \\
\hline R.E. at UZA-fuel type level & No & & 0.381 & 0.128 & No & & 0.337 & 0.145 \\
\hline R.E. at UZA level & No & & 0.104 & 0.312 & No & & 0.079 & 0.339 \\
\hline Log-likelihood & -4800.7 & & -4724.3 & & -4692.4 & & -4620.1 & \\
\hline
\end{tabular}

Notes: No. of observations: 2907. The choice set consists of all available make-fuel type combinations (e.g., a Gillig diesel bus). The $1^{\text {st }}$ and $3^{\text {rd }}$ specifications are multinomial logit regressions while the $2^{\text {nd }}$ and $4^{\text {th }}$ incorporate random effects at various levels. All regressions controls for year, fuel type, and make fixed effects as well as fuel-type specific time trends. 